\title{
DIREITO PENAL INTERNACIONAL, ESTADO CONSTITUCIONAL E O PROBLEMA DA MITIGAÇÃO DA SOBERANIA NA PERSECUÇÃO DOS CRIMES INTERNACIONAIS PRÓPRIOS
}

\section{Marcus Vinícius Xavier de Oliveira ${ }^{1}$}

\section{Resumo}

No presente trabalho são discutidos os temas relativos à internacionalização do Direito Penal, a consolidação da justiça internacional na persecução dos crimes internacionais próprios - através dos Tribunais Penais Internacionais (direct enforcement) ou da jurisdição universal (indirect enforcement) - e o problema da relação entre soberania e jurisdição penal internacional, tencionando solucionar a possível controvérsia entre aquela consolidação e uma possível mitigação da soberania estatal. Esta solução é encontrada em dois polos distintos: de um lado, o contínuo progresso da justiça internacional tende a mitigar a jurisdição penal dos Estados em relação à anterior exclusividade para a persecução dos crimes internacionais; de outro lado, este progresso ainda está condicionado à cooperação dos Estados, sem a qual a justiça internacional não logra eficácia, donde o dever de os Estados cooperarem internacionalmente para se enfrentar o problema da impunidade dos crimes contra a humanidade.

Palavras-chave: Justiça Penal Internacional, Crimes Internacionais Próprios, Soberania, Cooperação Internacional

\section{INTRODUÇÃO}

O objetivo geral do presente trabalho, que tem objeto de estudo temas do Direito Penal Internacional, é o de comprovar o dever de os Estados cooperarem internacionalmente na persecução penal dos autores de crimes internacionais, em especial nos denominados crimes internacionais próprios, isto é, aquele conjunto de delitos tipificados através de tratados e/ou costumes internacionais - e por isso também denominados Crimes Under International Law ou Crimes Against International Law - nos quais estão implicados os interesses comuns da humanidade, na medida em que esses ilícitos violam quer princípios fundamentais da sociedade internacional v.g, igualdade soberana dos Estados, solução pacífica dos conflitos e a proscrição da guerra (crime de agressão) -, quer os direitos internacionalmente assegurados à pessoa humana, como fica bastante evidente nos crimes de

\footnotetext{
${ }^{1}$ Professor Adjunto da Universidade Federal de Rondônia. Doutor (UERJ) em Direito. Líder do Jus Gentium - Grupo de Estudos e Pesquisas em Direito Internacional. Membro do Grupo de Pesquisas em Teoria Política Contemporânea. E-mail: marcusoliveira@unir.br.
} 
genocídio e contra a humanidade, quer, por fim, os princípios, regras e costumes internacionais do jus in bellum, o que se dá nos casos dos crimes de guerra, isto é, os crimes que violam as regras do Direito Internacional Humanitário.

Essas quatro modalidades de crimes internacionais se encontram, passados largos anos desde Nuremberg e Tóquio, tipificados nos artigos 5o (que delimita a competência do Tribunal Penal Internacional (doravante TPI) aos crimes de genocídio, crimes contra a humanidade, crimes de guerra e o crime de agressão) e $6^{\circ}$ a $8^{\circ}$ do Estatuto do Tribunal Penal Internacional ${ }^{2}$ (doravante ETPI ou Estatuto de Roma) ${ }^{3}$ - e por isso também denominados de Core Crimes por setem considerados como os mais graves que se possa cometer na perspectiva do Direito Internacional, e por isso passíveis de punição com a sanção jurídica mais dura admitida na sociedade internacional, a pena de caráter perpétuo ${ }^{4}$.

Contudo, este artigo, conforme identificado em seu título, tem por meta discutir o problema da relação entre soberania e o Direito Penal Internacional. Por isso, no presente trabalho não serão desenvolvidos os problemas relacionados aos crimes internacionais, mas somente aqueles tópicos que permitirão compreendê-los a partir de um conjunto de paradigmas que, sendo fundamentos teóricos, deverão aparecer, explícita ou implicitamente, durante todo o percurso da argumentação que será desenvolvida.

\section{DIREITO PENAL E GLOBALIZAÇÃO}

Neste primeiro tópico serão apresentados os temas relacionados à relação, nem sempre cordial e harmônica, entre Direito Penal e globalização, tendo como paradigma a internacionalização do Direito Penal. Em síntese, serão discutidos os conflitos, reais ou aparentes, entre os princípios da cooperação internacional e da soberania pretensamente desencadeados pela globalização.

\footnotetext{
${ }^{2}$ Estatuto de Roma do Tribunal Penal Internacional, ratificado pelo Brasil através do Decreto Legislativo n. 112/2002.

${ }^{3} \mathrm{O}$ crime de agressão, desde a vigência do ETPI em 2002, estava submetido à cláusula suspensiva de vigência contida no artigo $5^{\circ}$, 2 do ETPI, que permitia o exercício jurisdicional do TPI sobre esse crime somente após a tipificação de seus elementos, o que foi feito, em parte, por ocasião da Conferência de Revisão do ETPI ocorrida em Kampala, Uganda, entre 31 de março e 11 de junho de 2010, restando, no entanto, a sua confirmação pela Assembleia dos Estados Partes do TPI a ocorrer em 2017. Consultar, nesse sentido, o Regulamento do TPI sobre os elementos dos crimes já revisado, disponível em http://www.icccpi.int/NR/rdonlyres/A851490E-6514-4E91-BD45-AD9A216CF47E/283786/ElementsOfCrimesSPAWeb.pdf, acessado em 20/08/2011, às 14:31:00.

${ }^{4}$ EX vi artigo 77, 1, b do ETPI. É importante demarcar a proscrição da pena de morte no atual contexto do Direito Penal Internacional, já que, diversamente do que ocorreu em Nuremberg e em Tóquio, também nesse tocante, o Direito Internacional dos direitos humanos opera uma força extremamente importante, ex vi, e.g., do artigo 6 do Pacto Internacional dos Direitos Civis e Políticos de 1966, bem como de seu Segundo Protocolo Facultativo, aprovado pela Assembleia Geral das Nações Unidas mediante a Resolução n. 44/128, de 15 de dezembro de 1989, que tem por meta a abolição da pena de morte.
} 


\section{Enfrentando a ambiguidade do conceito "globalização"}

Embora fosse interessante, ou mesmo necessário, esta primeira parte não tem a intenção de fazer uma exposição exauriente sobre o fenômeno da globalização, tema que, per se, reúne uma série de complexidades e abrangências que ocupariam todo o trabalho. Assim, para enfrentá-lo se adotaram dois subtópicos que serão percorridos a partir de ligeiras sínteses: o primeiro será conceitual e o segundo fenomenológico.

Conceitualmente, o vocábulo globalização designa, conforme o assento recaia quer sobre sua origem quer sobre aspectos particulares, a realidades bastante diversas entre si.

Se a análise recair sobre a origem do fenômeno, nada seria mais incorreto do que situá-lo no desenvolvimento econômico-tecnológico iniciado a partir do final da década de 1980 com o surgimento daquilo que se tem denominado de "sociedade informática" (Alexander King), "aldeia global" (McLuhan), "economiamundo", "sistema-mundo", "shopping center global", "capitalismo global", dentre outras tantas 5 , conceitos que buscam demarcar o seu nascimento nos diversos processos econômicos, financeiros e tecnológicos implicados na abertura das fronteiras dos Estados pela transnacionalização da economia e na contração do espaço-tempo a partir dos fluxos contínuos de comunicação propiciados pelo desenvolvimento tecnológico, mormente no contexto da rede mundial de computadores, com a consequente estandardização das produções industrialtecnológicas em escala global e na formação contínua de uma cultura de massas que se expande cada vez mais sobre a face de a terra.

Mas se não estes processos econômico-tecnológicos, o que teria dado origem à globalização?

Para enfrentar a este questionamento será útil formular um novo: das duas grandes religiões mundiais hoje existentes - cristianismo e islamismo ${ }^{6}$-, a qual se pode atribuir uma origem recente e, mais ainda, ocidental? A nenhuma, muito embora se possa afirmar que não existiria hoje o ocidente sem as profundas influências que estas duas religiões exercem em sua cultura, seja na afirmação de sua identidade (cristianismo), seja no desencadeamento de conflitos religioso-culturais pretensamente decorrentes do crescimento do número de adeptos (islamismo) ocasionado pela imigração de pessoas oriundas de países majoritariamente islâmicos, pelo proselitismo religioso, dentre outros fatores.

Se estas religiões, com origens tão remotas histórica, geográfica e culturalmente, se manifestam como um dos tantos fatores que exercem um papel preponderante na afirmação identitária ocidental contemporânea,

\footnotetext{
${ }^{5}$ Todas estas referências conceituais foram extraídas de IANNI, Octávio. Teorias da globalização, 12 ed., Rio de Janeiro: Civilização Brasileira, 2004, pp. 14-15.

${ }^{6}$ Estas duas religiões contam, respectivamente, com 2,17 bi e 1,58 bi de fiéis, conforme dados levantados pela Pew-Templeton na Global Religious Future Project, disponível em http://www.globalreligiousfutures.org/explorer\# / ssubtopic=15\&chartType=bar\&year=2010\&data_type=number\&religious_aff 
mesmo naquilo que Samuel Huntington denomina de choque de civilizações ${ }^{7}$, a que fenômeno atribuir as suas inserções nessa cultura a não ser à globalização?

Nesse sentido, Odete Maria de Oliveira ${ }^{8}$ logra dilucidar aspectos importantes desse fenômeno que tanta controvérsia suscita em nível teórico, em especial de sua origem, a saber: a perene insatisfação do homem com a sua situação presente, e a busca, além das fronteiras dadas e conhecidas, de condições mais benfazejas a um ideal de vida boa; esse ideal incita aos mais diversos povos à expansão de seu espaço de vivência mediante a exploração de novas terras, de novos campos de atuação, de superação de suas próprias limitações pessoais e tecnológicas, circunstâncias que tanto podem suscitar o contato pacífico entre povos diferentes, como a guerra sem tréguas tendente à eliminação da diferença e à tomada da terra e suas respectivas riquezas.

Assim, a isto que se denomina de globalização não é nem um fenômeno recente nem uma consequência da técnica e da economia contemporâneas, mas antes uma assinatura da história e cultura humanas, já que estes fluxos contínuos de expansão também são submetidos a fluxos contínuos de refração, pelo que seria mais correto afirmar-se que, do ponto de vista histórico, a humanidade está continuamente submetida a processos de expansão e de contração dos processos globalizantes?.

iliation=all \&destination=to \& countries=Worldwide, acessado em 10/07/2013, às 17:50:00.

${ }^{7}$ HUNTINGTON, Samuel P. “The Clash of Civilizations?”, Foreign Afairs vol. LXXII, n. 3, 1993, pp. 22-49. Nesse artigo, depois convertido em um livro que se tornou fundamental para a compreensão da política internacional após a queda do mundo de Berlim em 1989, Huntington afirma que os novos conflitos a surgirem não serão mais de caráter ideológico (capitalismo v. comunismo), nem de caráter econômico, mas antes culturais, isto é, entre as civilizações ocidental e oriental. Contra a tese de Huntington, Roberto Esposito levanta alguns questionamentos interessantes, em que se evidencia o caráter arbitrário dessa doutrina: "A mesma consideração se pode fazer, de forma ainda mais clara, para as quatro décadas que procederam ao final da Segunda Guerra Mundial, quando a ordem bipolar do planeta não deixou margens ao imprevisto, a ponto de que o que ocorreu, em cada um dos dois blocos, pareceu ser o resultado quase automático de um jogo conhecido e previsível em todos seus movimentos. Não obstante, esta ordem política que parecia ter que governar ainda por muito mais tempo as relações internacionais, faz-se em pedaços de repente. Primeiro na forma de implosão, o sistema soviético, e depois, de explosão, com o terrorismo. Por quê? Como se explica esta inesperada mudança de fase? E de onde, exatamente, se origina? A resposta que geralmente afronta a estas interrogações se faz referindo-se ao final da guerra fria e à conseguinte chegada da globalização. Contudo, deste modo, se corre o risco de intercambiar a causa com o efeito, oferecendo como explicação o que deveria ser explicado. Também a tese, mais recente, que faz referência ao chamado choque de civilizações, se bem indica, em termos mais dramatizados, uma emergência ou pelo menos um risco efetivamente presente, não ajuda a enfrentar o tema com uma interpretação adequada. Por que as civilizações, se quisermos utilizar esta palavra complexa, depois de terem convivido pacificamente por mais de meio milênio, ameaçam hoje se enfrentar com resultados catastróficos?". ESPOSITO, Roberto. "Filosofia e biopolítica", trd. Marcus Vinícius Xavier de Oliveira, Ethic@, vol 9, n. 2, Florianópolis, 2010, pp. 369-382.

${ }^{8}$ DE OLIVEIRA, Odete Maria. Teorias globais, Vol. I: Elementos e estruturas, Ijuí: Editora Unijuí, 2005, pp. 31-43. Na mesma senda, embora enfocando o início das grandes navegações e das conquistas a oeste e a leste pelos Estados europeus de novos territórios e mercados, bem como as influências recíprocas para as culturas envolvidas, para o bem e para o mal, se orienta BROOK, Timothy. O chapéu de Vermeer: o século XII e o começo do mundo globalizado, trd. Maria B. de Medina, Rio de Janeiro: Record, 2012. Boaventura de Sousa Santos tem a mesma interpretação, embora sob uma perspectiva crítica, na qual aponta as assimetrias estruturais entre os diversos atores envolvidos, em especial os Estados em desenvolvimento em relação aos Estados desenvolvidos. SANTOS, Boaventura de Sousa. Os processos da globalização. Disponível em http://www.eurozine.com/articles/2002-08-22-santos-pt.html, acessado em 20/02/2011, às 23:35:00.

${ }^{9}$ DE OLIVEIRA, Teorias globais..., p. 31 . 
Timothy Brook ${ }^{10}$, para explicar esta potência de expansão e de intercomunicação congênita às culturas humanas no âmbito daquilo que ele denomina de mundo globalizado, e que no seu pensar se inicia com o período das grandes navegações, se utiliza da metáfora da rede de Indra:

O budismo usa imagem semelhante para descrever a interligação de todos os fenômenos. É a rede de Indra. Quando Indra criou o mundo, teceu-o como uma teia, e em cada encontro de fios dessa teia havia uma pérola amarrada. Tudo o que existe ou já existiu, toda ideia que pode ser pensada, todo dado que é verdadeiro - todo dharma, na linguagem da filosofia indiana - é uma pérola da rede de Indra. Não só cada pérola está amarrada a todas as outras por meio da teia na qual está pendurada, como na superfície de cada pérola se refletem todas as outras pérolas da rede. Tudo o que existe na teia de Indra implica tudo mais que existe.

Com esta metáfora da rede de Indra torna-se possível explicar a ideia central que norteia a interpretação ora dada ao fenômeno: nenhuma cultura, nenhum agrupamento humano, está condicionada a se encerrar permanentemente no contexto de seu próprio mundo da vida; a própria ideia de pureza cultural, ínsita ao encerramento interfronteiriço, manifesta uma lógica de exclusão, de eliminação da alteridade, de superioridade em relação aos diferentes que, se expressada na forma de uma política imunitária ${ }^{11}$, tende à sua eliminação, física ou moral ${ }^{12}$, tal como o evidencia os diversos genocídios que a história humana tem presenciado.

Assim, como forma de se diferençar realidades tão distintas conceitual e historicamente, é possível utilizar-se duas palavras-chave para compreender fenomenologicamente aquilo que se denomina de globalização: a) mundo globalizado e b) globalização em sentido estrito.

No sentido que se vem até agora interpretado, o termo globalização pode ser tomado como sinônimo de mundo globalizado (Timothy Brook), a significar, como já afirmado, os mais variados processos históricos pelos quais os homens e as sociedades nas quais eles vivem se expandem, geográfica e culturalmente para além de suas próprias fronteiras, propiciando quer o choque quer o contato amistoso.

Mas globalização também significará, em sentido estrito, esse processo hoje experienciado

\footnotetext{
${ }^{10}$ BROOK, O chapéu de Vermeer..., p. 33.

${ }^{11}$ A expressão imunidade é aqui utilizada na perspectiva dada por Roberto Esposito, em especial em seus livros ESPOSITO, Roberto. Bíos: biopolítica e filosofia, Turín: Einadi, 2004, pp. 41-77; ESPOSITO, Roberto. Immunitas. Protezione e negazione dela vitta, Turín: Einaudi, 2002.

${ }^{12}$ Michel Foucault em seu curso no Collège de France Em defesa da sociedade expressa esta lógica imunitária em termos biopolíticos quando analisa o problema das políticas raciais com as seguintes palavras: "[...] o racismo vai permitir estabelecer, entre a minha vida e a morte do outro, uma relação que não é uma relação militar e guerreira de enfrentamento, mas uma relação do tipo biológico: "quanto mais as espécies inferiores tenderem a desaparecer, menos degenerados haverá em relação à espécie, mais eu não enquanto indivíduo mas enquanto espécie - viverei, mais forte serei, mais vigoroso serei, mais poderei proliferar. A morte do outro não é simplesmente a minha vida, na medida em que seria minha segurança pessoal; a morte do outro, a morte da raça ruim, da raça inferior (ou do degenerado, ou do anormal), é o que vai deixar a vida em geral mais sadia; mais sadia e mais pura [...] Se o poder de normalização quer exercer o velho direito soberano de matar, ele tem de passar pelo racismo. E se, inversamente, um poder de soberania, ou seja, um poder que tem direito de vida e morte, quer funcionar com os instrumentos, com os mecanismos, com a tecnologia da normalização, ele também tem de passar pelo racismo. É claro, por tirar a vida não entendo simplesmente o assassínio direto, mas também tudo o que pode ser assassínio indireto: o fato de expor à morte, de multiplicar para alguns o risco de morte ou, pura e simplesmente, a morte política, a expulsão, a rejeição, etc. (grifo nosso) FOUCAULT, Michel. Em defesa da sociedade, trd. Maria E. Galvão, São Paulo: Martins Fontes, 2002, pp. 305-306.
} 
contemporaneamente na forma da imediata intercomunicação e das circulações de informações, riquezas e pessoas em razão:

1) do próprio regime econômico majoritariamente presente no mundo contemporâneo, o capitalismo global;

2) o desenvolvimento da tecnologia da comunicação, em especial a internet, e que deu origem àquilo que Manuel Castells ${ }^{13}$ denominará de sociedade da informação e do conhecimento, cujas principais características serão: a) a contração do tempo e do espaço em razão da imediatidade dos fluxos de comunicação, b) o papel que joga o conhecimento no sistema produtivo, tanto no que concerne à própria produção tecnológica como, principalmente, na empregabilidade e na ocupação dos postos de gerenciamento nas empresas, mormente as transnacionais, e c) na conformação de uma nova identidade, a partir da qual os parâmetros de vida boa não são mais aquelas presentes e manifestadas na comunidade nacional, mas sim na comunidade global; e

3) uma profunda transformação nos processos de tomada de decisões políticas em nível nacional e internacional.

Nesse último sentido, é possível pensar-se a globalização a partir dos conceitos de desterritorialização e reterritorilização ${ }^{14}$ : com a emergência de relações sociais inter e transnacionais cada vez mais amplas e difusas, inclusive de caráter ilícito, a competência do Estado para decidir acerca de suas políticas legislativas, econômicas, administrativas etc vem cedendo passo frente à sociedade internacional, que passa de forma reiterada a estabelecer parâmetros gerais de condução para a governança nacional.

Assim, desterritorialização e reterritorilização identificam o deslocamento dos centros de competência/decisão, vale dizer, do Estado para a sociedade internacional, na qual os Estados pactuam modos e princípios gerais para se enfrentar determinado problema internacional, bem como um deslocamento do centro de referências de todas as sociedades implicadas na globalização.

Isto não quer significar, no entanto, atribuir ao Estado uma postura passiva, de mero receptor das regras externas. Quer significar, isto sim, uma profunda transformação no processo de decisão política, na qual o Estado, nos diversos embates internacionais sobre a determinação de uma possível política internacional, busca, em relação a suas contrapartes internacionais (outros Estado, organizações internacionais, ONGs etc), estabelecer,

\footnotetext{
${ }^{13}$ CASTELSS, Manuel. A era da informação: economia, sociedade e cultura, vol. I: A sociedade em rede, trd. Roneide Venancio Majer, 6 ed., São Paulo: Paz e Terra,2002; CASTELLS, Manuel. A era da informação: economia, sociedade e cultura, vol. II: O poder da identidade, trd. Klauss B. Gehardt, 5 ed., São Paulo: Paz e Terra, 2006.

${ }^{14}$ SANTOS, Boaventura de Sousa. Os processos da globalização. Disponível em http://www.eurozine.com/articles/2002-0822-santos-pt.html, acessado em 20/02/2011, às 23:35:00. DE OLIVEIRA, Marcus Vinícius Xavier. "Da inconstitucionalidade dos artigos 70, $\$ 11^{\circ}$ e 80 do Código Penal por violação ao princípio ne bis in idem”, Revista Quaestio Iuris, Rio de Janeiro, v. 1, n. 10, 2012, pp. 1-31.
} 
discursivamente, o conteúdo dessa política.

Isto fica evidente, por exemplo, na verdadeira "luta"15 que se trava entre os mais diversos Estados no contexto de uma conferência internacional em que se discute o estabelecimento de um tratado internacional multilateral, conforme afirmado por José Antonio Pastor Ridruejo ao criticar as teorias negacionistas - jurídicas ou sociológicas - do Direito Internacional ${ }^{16}$ :

E com toda segurança, o Direito Internacional tem maior credibilidade para os próprios Estados que para muitos dos impugnadores teóricos da disciplina. Quem tenha seguido de perto os trabalhos de uma conferência intergovernamental sobre codificação e desenvolvimento progressivo do Direito Internacional, chegou ao convencimento de que os Estados tomam muito mais a sério suas normas que os incrédulos e superficiais teorizadores [...] Aos Estados não lhes é indiferente que o resultado seja ou um ou outro porque valorizem o Direito Internacional positivo, ainda que seja somente como um condicionante a mais no processo político de tomada de decisões, porque para eles os tratados internacionais não são letra morta nem uma simples chiffon de papier, porque atribuem grande importância ao princípio pacta sunt servanda que sabem ser respeitado de modo geral.

Nesse ponto, portanto, não resta a menor dúvida de que a globalização tem o efeito de incitar a adoção de projetos e programas internacionais cooperativos, por meio do Direito Internacional, como forma de se enfrentar, coletivamente, problemas que não dizem respeito ao Estado, mas à sociedade internacional, do que decorre a crescente internacionalização do direito em seus mais variados temas, e que se dá em nível universal, regional ou sub-regional.

Tome-se como exemplo desse tema o problema relacionado ao crime de lavagem de capitais, uma espécie de crime transnacional, isto é, uma modalidade de crime internacional que somente será efetivado mediante a sua tipificação nas legislações nacionais dos Estados Partes do tratado internacional. Uma análise dos princípios instrumentos internacionais sobre o assunto demonstrará que todos os tratados internacionais que versam sobre os problemas da macrocriminalidade econômica concitam os Estados Partes a criminalizarem este comportamento (para ficarmos nos tratados internacionais do sistema onusiano: a convenção de Viena sobre o Tráfico de Entorpecentes ${ }^{17}$, sobre o Crime Organizado ${ }^{18}$, a Convenção Contra a Corrupção ${ }^{19}$ e o Tratado Internacional Contra o Financiamento do Terrorismo ${ }^{20}$ ), sendo este fato expressamente reconhecido na

\footnotetext{
${ }^{15}$ Sobre a "luta" para a aprovação do ETPI no curso da Conferência Diplomática de Roma entre os dias 15 de junho a 17 de julho de 1998, consulte a narrativa de JAPIASSÚ, Carlos Eduardo Adriano. O Tribunal Penal Internacional: a internacionalização do direito penal, Rio de Janeiro: Lumen Juris, 2004, pp. 112-116.

${ }^{16}$ PASTOR RIDRUEJO, Jose Antonio. Curso de derecho internacional público y organizaciones internacionales, 4 ed., Madri: Tecnos, 1992, p. 41

${ }^{17}$ Convenção contra o Tráfico Ilícito de Entorpecentes e Substâncias Psicotrópicas, ratificada pelo Brasil através do Decreto Legislativo n. 162/1991.

${ }^{18}$ Convenção das Nações Unidas contra o Crime Organizado Transnacional, ratificada pelo Brasil através do Decreto Legislativo n. $231 / 2003$.

${ }^{19}$ Convenção das Nações Unidas contra Corrupção, ratificada pelo Brasil através do Decreto Legislativo n. 348/2008.

${ }^{20}$ Convenção Internacional para a Supressão do Financiamento do Terrorismo, ratificada pelo Brasil através do Decreto Legislativo n. 769/2005.
} 
exposição de motivos da Lei 9613/1998, que tipificou esse comportamento no Brasil21.

Para ilustrar esta necessidade de cooperação, é interessante ter em conta os valores obtidos pela macrocriminalidade internacional, conforme exposto no relatório do Escritório das Nações Unidas para Drogas e Crimes (doravante UNODC) - The globalization of crime: a transnacional organized crime threat assessment-, publicado em $2010^{22}$ :

\begin{tabular}{|l|c|}
\hline Atividade Ilícita & Valor Estimado - US\$ \\
\hline 1. Tráfico de pessoas para fins de exploração sexual. Destino: Europa & $3 \mathrm{bi}$ \\
\hline 2. Contrabando de imigrantes: & $6,6 \mathrm{bi}$ \\
\hline a) América Latina para EUA & $150 \mathrm{mi}$ \\
\hline b) África para Europa & \\
\hline 3. Tráfico de Cocaína: & $33 \mathrm{bi}$ \\
\hline a) Região Andina para EUA & $34 \mathrm{bi}$ \\
\hline b) Região Andina para Europa & \\
\hline 4. Tráfico de Heroína & $13 \mathrm{bi}$ \\
\hline a) Afeganistão para Federação Russa & $20 \mathrm{bi}$ \\
\hline b) Afeganistão para Europa (exceto Rússia) & \\
\hline 5. Tráfico de Armas & $20 \mathrm{mi}$ \\
\hline a) EUA para México & $33 \mathrm{mi}$ \\
\hline b) Leste-Europeu para Mundo & $8,2 \mathrm{bi}$ \\
\hline 6. Falsificação de Produtos - Ásia para Europa & $1,6 \mathrm{bi}$ \\
\hline 7. Falsificação de Remédios - Ásia para Sul e Leste Asiático e África & $100 \mathrm{mi}$ \\
\hline 8. Pirataria Marítima - Costa Somália & \\
\hline 9. Cybercrimes & $1 \mathrm{bi}$ \\
\hline a. Roubo de identificações/dados & $250 \mathrm{mi}$ \\
\hline b. Pornografia infantil & \\
\hline
\end{tabular}

Ora, se a lavagem de capitais, como já afirmado, é um crime previsto nas principais convenções internacionais, universais e regionais, que têm por escopo o enfrentamento da macrocriminalidade econômica, é em razão do fato dela ser um dos principais instrumentos utilizados pela criminalidade organizada para fazer circular, sem rastros de sua origem, a enorme soma de valores obtidos ilicitamente. E o que teria dado origem, em nível infraestrutural, a essa preocupação internacional.

Conforme o Escritório das Nações Unidas sobre Drogas e Crimes ${ }^{23}$ o caráter transnacional da lavagem

\footnotetext{
21 "8. Portanto, o presente projeto se constitui na execução nacional de compromissos internacionais assumidos pelo Brasil, a começar pela Convenção de Viena de 1988”. Disponível em www.coaf.fazenda.gov.br/downloads/Lei\%209613.pdf. Acessado em 20/04/2012, às 14:00:00.

${ }^{22}$ UNITED NATIONS OFFICE ON DRUGS AND CRIMES. The globalization of crime: a transnational organized crime threat assessment, UNODC: Viena, 2010, pp. 16-17. Disponível em http://www.unodc.org/documents/data-and analysis/tocta/TOCTA_Report_2010_low_res.pdf, acessado em 15/02/2011, às 14:00:00.

${ }^{23}$ ESCRITÓRIO DAS NAÇÕES UNIDAS SOBRE DROGAS E CRIMES. Guia de estudos: Convenção Internacional para a Eliminação do Financiamento do Terrorismo e Lavagem de Dinheiro. Disponível em http://www.ri.pucminas.br/minionu/GuiaUNODC.pdf, acessado em 20/07/2012, às 17:22:00.
} 
de dinheiro ganhou abrangência internacional de forma muito mais ampla em razão da globalização e do desenvolvimento da tecnologia de informação que se inicia a partir da década de 1970, o que possibilitou a mobilidade imediata de recursos no sistema financeiro internacional:

A Globalização gerou uma problemática para os bancos e instituições financeiras: com a digitalização da economia, reconhecer efetivamente seus clientes tornou-se um grande desafio. Isso porque agora, os bancos mantêm poucas relações físicas, face-a-face, com os titulares das contas. Assim, a vigilância, o controle e a fiscalização, que até então se utilizava dos registros e documentos financeiros, terão também que se digitalizar e incorporar novas tecnologias para combater os crimes financeiros de igual para igual. A lavagem de dinheiro tornou-se virtual. Isto é um fato. O novo mercado único, integrado e digitalizado, circula vultosos montantes de dinheiro em nanossegundos, e permite que o dinheiro viaje por diferentes jurisdições e fiscalizações domésticas, o que torna mais difícil ainda de se detectar a origem e a finalidade de cada transação.

Entretanto, é bastante óbvio que a globalização não está, e nem poderia, imune às críticas as mais variadas, tendo em conta, principalmente em seu aspecto econômico-financeiro, o aumento exponencial das assimetrias entre as diversas sociedades ${ }^{24}$, e que têm o condão de expor as profundas contradições que o sistema capitalista, em sua última fase de desenvolvimento, produz na forma da exclusão de uma ampla maioria de pessoas ${ }^{25}$ de terem acesso não aos bens de consumo de última geração, mas às condições mínimas de vida digna ${ }^{26}$.

\section{Globalização e a internacionalização do Direito Penal}

Se fosse possível sintetizar a mentalidade do pensamento jurídico moderno quanto à relação entre direito, nacional e internacional, e Estado, esta seria: no princípio era o Estado!27

Esta racionalidade, derivada do sistema westfaliano, concede àquele, na qualidade de entidade políticojurídica dotada de soberania territorial, imunidade jurídica para o exercício de suas jurisdições ${ }^{28}$, pela qual ele

\footnotetext{
${ }^{24}$ Roberto Esposito interpreta este aspecto negativo da globalização em passagens extraordinárias de lucidez e rigor filosófico, tomando como referencial interpretativo o paradigma do Estado de natureza. ESPOSITO, Roberto. Comunidade e violência, in DANNER, Fernando, DANNER, Leno Francisco (Org). Temas de filosofia política contemporânea, trd. Marcus Vinícius Xavier de Oliveira, Porto Alegre: Editora Fi, 2013, pp. 13-32.

${ }^{25}$ Boaventura de Sousa Santos chama a atenção para o aumento das assimetrias não somente entre Estados desenvolvidos e Estados em desenvolvimento, mas também no âmbito dos próprios países ricos, mediante o crescimento daquilo que se tem denominado de terceiro mundo interior. SANTOS, Boaventura de Sousa. Para um novo senso comum: a ciência, o direito e a política na transição paradigmática. Vol. 1: A crítica da razão indolente: contra o desperdício da experiência, São Paulo: Cortez, 2001, p. 56.

${ }^{26}$ Nesse sentido, IANNI. Teorias da globalização, pp. 27-72; SANTOS. Os processos da globalização, passim.

${ }^{27}$ A alusão ao capítulo 1 do Evangelho de João não é banal, na medida em que, teoricamente, nos orientamos pelo paradigma epistemológico desenvolvido por Carl Schmitt e Giorgio Agamben da teologia política, segundo o qual, "Todos os conceitos decisivos da moderna teoria do Estado são conceitos teológicos secularizados”. SCHMITT, Carl. Teologia política, trad. Elisete Antoniuk, Belo Horizonte: Del Rey, 2006; vide também AGAMBEN, Giorgio. Il regno e la gloria: per una genealogia teologica dell'economia e del governo. Homo sacer, II.2, Vicenza: Neri Pozza, 2007.

${ }^{28}$ Soberania é o conceito que a teoria do Estado, o direito constitucional e o Direito Internacional atribuem ao conjunto de competências asseguradas ao Estado pelo Direito Internacional enquanto entidade internacional independente, mais
} 
impõe à sua população o dever de cumprimento de suas normas mediante a ameaça de sanção jurídica, civil ou penal, bem como, por ser igualmente soberano em relação aos demais Estados, não se obrigar internacionalmente sem o seu consentimento. Em outros termos, a afirmação histórica dos princípios modernos da não intervenção em assuntos de jurisdição interna e da igualdade soberana dos Estados, conforme expressamente previsto no artigo 2, 1 e 7 da Carta das Nações Unidas.

Para Pastor Ridruejo ${ }^{29}$, a estrutura da sociedade internacional no sistema westfaliano se constituiria numa estrutura justaposta, no qual o Direito Internacional teria por finalidade, conforme a Corte Permanente de Justiça Internacional (doravante CPJI) no paradigmático caso Lótus, «[...] régit les rapports entre des Etats indépendants... en vue de régler la coexistence de ces communautés indépendantes ou en vue de la poursuite de buts communs $\gg(\text { grifos no original })^{30}$. Em outras palavras, o Direito Internacional principia com os Estados, para regular os comportamentos dos Estados e para satisfazer aos interesses dos Estados.

Contudo, conforme o mesmo Pastor Ridruejo, as diversas viragens e transformações sofridas pela sociedade internacional ao longo dos séculos XIX e XX, e que se manifestam de forma incisiva após 1945, e espocam nos finais da década de 1980 com a globalização, levou esta sociedade de justaposição a se recompor paulatinamente numa nova estrutura, agora caracterizada como uma sociedade de coordenação, nos quais

[...] interesses, por exemplo, relativos a alguns aspectos da proteção da pessoa humana (proibição da escravidão, tráfico de mulheres brancas) ou às comunicações, cuja satisfação em comum encontra sua base em tratados internacionais, preferencialmente multilaterais. Surge assim, progressivamente, o Direito Internacional da Cooperação ou Coordenação, que conhece um notável impulso a partir de 1945, quando finaliza da segunda guerra mundial ${ }^{31}$.

Uma parte significativa dos autores parece concordar que o final da Guerra Fria, paradigmaticamente identificada com a queda do muro de Berlim em 1989, foi responsável, para empregar a metáfora de Norberto Bobbio $^{32}$, pelo desbloqueio das vias para um novo desenvolvimento do Direito Internacional, de seus institutos e de sua organização. Assim ocorreu no que José Augusto Lindgren Alves denomina de globalização dos direitos humanos, ao menos em nível político, por ele situado com a realização da Conferência Mundial dos Direitos Humanos de Viena em de 1993³; o mesmo no âmbito do Conselho de Segurança das Nações Unidas

propriamente interpretáveis a partir do conceito de jurisdição, que decomposto se manifesta em três: jurisdição legislativa (prescriptive jurisdiction), jurisdição adjudicativa ou jurisdicional (adjudicative jurisdiction) e de execução forçada das sanções legais (executive jurisdiction). JANKOV, Fernanda F. F. Direito Internacional penal: mecanismos de implementação do Tribunal Penal Internacional, São Paulo: Saraiva, 2009, pp. 66-83.

${ }^{29}$ PASTOR RIDRUEJO. Curso de derecho internacional público..., p. 70.

${ }^{30} \mathrm{Apud}$ WEIL, Prosper. Le droit international en quête de son identité, Cours géneral de droit international public, RCAD vol. 237/1992, pp. 09-370 (p. 34).

${ }^{31}$ PASTOR RIDRUEJO, Curso de derecho internacional ..., p. 70.

${ }^{32}$ BOBBIO, Norberto. O problema da guerra e as vias da paz, trd. Álvaro Lorencini, São Paulo: Editora UNESP, 2003, p. 49 et seq.

${ }^{33}$ ALVES, José Augusto Lindgen. Os direitos humanos como tema global, São Paulo: Perspectiva, 2011 , pp. 23 et seq. 
(doravante CSONU), que passou, dentro de seus critérios de seletividade política, a ter um papel mais ativo após a cessação dos conflitos ideológicos entre USA/URSS ${ }^{34}$, o que redundou para o Direito Penal Internacional em sua primeira manifestação concreta após os julgamentos de Nuremberg e Tóquio, com a criação do Tribunal Penal Internacional para a Ex-Iugoslávia (doravante TPIExlug), e logo após, o Tribunal Penal Internacional para Ruanda (doravante TPIR) ${ }^{35}$.

Seria, então, esta a razão pela qual hoje a sociedade internacional se encontra nesse processo de conformação de uma sociedade coordenada, e não mais justaposta. Contudo, já antes do fim da Guerra Fria se tem indícios desse rumo, como fica evidente no Parecer Consultivo da Corte Internacional de Justiça (doravante CIJ) sobre as reservas à Convenção para a Prevenção e a Repressão do Crime de Genocídio ${ }^{36}$, segundo a qual:

Os princípios nos quais ela se fundamenta são reconhecidos pelas nações civilizadas, como obrigatórios aos Estados, independentemente de serem normas de uma Convenção Internacional; ela foi concebida como uma convenção de alcance universal; sua finalidade é puramente humana e civilizadora; os contratantes não auferem nem vantagens, nem desvantagens individuais; nem interesses próprios, mas um interesse comum. De onde é permitido concluir-se que o objeto e a finalidade da Convenção implicam, tanto no que respeita à Assembleia Geral, quanto aos Estados que a adotam, a intenção de reunir o maior número possível de participação.

Portanto, é nesse contexto de transformações ${ }^{37}$ que podem ser encontrados os traços daquilo que se tem denominado de internacionalização do direito, cuja caracterização fica mais clara com o seguinte quadro:

1) de um lado, uma contínua transferência de competências nacionais para a sociedade internacional, e que passam a ter no Direito Internacional o seu locus de regulação. Talvez os exemplos mais importantes sejam o da conversão do direito à guerra (jus ad bellum) em um direito de guerra (jus contra bellum e jus in bellum ${ }^{38}$ ) e em um direito do pós-guerra (jus post bellum) ${ }^{39}$ nos termos do

\footnotetext{
${ }^{34}$ LAMAZIÈRE, Georges. Ordem, hegemonia e transgressão, 2 ed., Brasilia: Fundação Alexandre de Gusmão, 2010, pp. 21-43.

${ }^{35}$ BADINTER, Robert. Soberania dos Estados: reflexões gerais, in CASSESSE, Antonio, DELMAS-MARTY, Mireille (Org.). Crimes internacionais e jurisdições internacionais, trd. Silvio Antunha, Barueri: Manole, 2004, pp. 49-58. Os Estatutos dos Tribunais Penais Internacionais para a Ex-Iugoslávia e Ruanda foram estabelecidos pelo Conselho de Segurança das Nações Unidas, respectivamente as Resoluções 827, de 25 de maio de 1993 e 955, de 08 de novembro de 1994.

${ }^{36}$ INTERNATIONAL COURT OF JUSTICE. Reservation to the Convention on the prevention and punishment of the crime of genocide. Advisory opinion of 28 May 1951.

${ }^{37}$ Prosper Weil, resgatando as lições de Maurice Bourquin de 1931, afirma que a ideia de que seria a queda do muro de Berlim e o fim do império soviético que teriam dado novo impulso ao Direito Internacional não passa de uma percepção equivocada da realidade internacional. Em verdade, reportando-se às liçōes de Gerald Fitzmaurice, o autor alude ao contínuo processo de transformaçōes e mudanças que acompanha o Direito Internacional. WEIL, Le droit international en quête..., pp. 26-28. No mesmo sentido segue a lição de Shabtai Rosenne, quando afirma que as transformações por que o Direito Internacional tem passado não thes são nem estranhas nem lhes retira o seu caráter perene como fator regulante da sociedade internacional. Muito pelo contrário, se o Direito Internacional ainda permanece como critério imperioso para as relações interestatais, é em razão mesmo dessa sua capacidade de adaptação às constantes mudanças por que tem passado a sociedade internacional, e isso em razão do papel preponderante que o princípio da boa-fé sempre ocupou no âmbito das relações internacionais. ROSENNE, Shabtai. The perplexities of modern international law, Leiden: Martinus Nijhoff Publishers, 2004, pp. 449-455.

${ }^{38}$ Jus in bellum deve ser entendido como sinônimo de direito humanitário.

${ }^{39}$ DE OLIVEIRA, Marcus Vinícius Xavier. Guerra ao terror: da biopolítica à bioguerra, Porto Velho: EDUFRO, 2013, pp. 91-95.
} 
Capítulo VII da Carta das Nações Unidas e os diversos processos internacionais de persecução penal pela prática dos Core Crimes (sinteticamente, de Nuremberg ao Tribunal Penal Internacional, passando pelo Tribunais Internacionais ad hoce os Tribunais Mistos); mas também, como no caso da União Europeia, o direito monetário. O que temos nessas hipóteses? Expressões até então da soberania nacional que passaram a ser reguladas pelo Direito Internacional (na última hipótese, pelo direito comunitário europeu), cujas normas expressam mais do que um interesse particular de todos Estados, um interesse comum daquilo que alguns internacionalistas têm denominado de comunidade internacional ${ }^{40}$.

2) de outro lado, uma contínua e ininterrupta regulamentação internacional, fundada sobre o princípio da cooperação nas mais diversas matérias como o Direito do comércio, do desenvolvimento, das comunicações, Direitos Humanos, Direito Penal, Direito Ambiental etc, da qual deriva, para os Estados, a necessidade, mesmo o dever, de harmonizar suas legislações em relação ao Direito Internacional.

Teoricamente, é interessante notar como estes novos campos de regulações internacionais (pelo que é mais correto falar-se em internacionalizações e não de internacionalização ${ }^{41}$ ) interferiram sobremodo na conformação teórica do próprio Direito Internacional mediante a sua compartimentação em um Direito Internacional Geral, de caráter majoritariamente consuetudinário ${ }^{42}$, e Direitos Internacionais Especiais forjados em tratados multilaterais, muitas vezes regulando temas intrincadamente técnicos e instituidores de organismos internacionais especializados (os exemplos do Direito do Comércio Internacional e do Direito Internacional dos

\footnotetext{
${ }^{40}$ TOMUSCHAT, Christian. Obligations arising for States without or against their will, RCADI 241, 1993, pp. 195-374. Nesse Cours, Tomuschat faz uma defesa teórica bastante sensata sobre o conceito de comunidade internacional a partir da perspectiva do constitucionalismo internacional, sem abordar, no entanto, o caso da unidade monetária na Europa, que à época não havia se concretizado ainda.

${ }^{41}$ DELMAS-MARTY, Mireille. Por um direito comum, trd. Maria E. de A. P. Galvão, São Paulo: Martins Fontes, 1994, pp. 47-58.

${ }^{42}$ Não se pode perder de vista que para o Direito Internacional, diversamente do que acontece nos direitos nacionais, mormente se pertencentes ao sistema romano-germânico, os costumes ainda se constituem nas principais e mais importantes fontes de direito (por todos, GUGGENHEIM, Paul. Contribution a l'historie des sources du Droit des Gens, RCADI, vol. 94 (1958-II), p. 36 : « [...] la coutume, au point de vue de la doctrine, est la source originair et la plus importante. C'est d'elle que la seconde des sources, la convention tira sa validité [...] )), donde, por exemplo, a crítica bastante interessante de Prosper Weil àquilo que ele denominou de "délices et poisons du "tout est coutume", dada a tendência contemporânea em considerar, e.g., resoluções de organizações internacionais, convenções em processo de ratificação, projetos de tratados internacionais, decisões de Cortes Internacionais etc como costumes internacionais não em formação, mas já dados pela prevalência da opinio juris em detrimento do usus, inclusive a partir de uma estranha teoria do "costume instantâneo". WEIL, Le droit international en quête, pp. 160-188. É nessa linha que M. Cherif Bassiouni, objetivando afastar a acusação de que os julgamentos por crimes contra a humanidade - em especial Regina vs. Finta - ofenderam ao princípio da irretroatividade da lei penal - tratar-se-ia, em sua interpretação, de um julgamento retrospectivo, e não retroativo -, concede ao Report presented to the preliminar Peace Conference by the Comissiono on the Responsabilities of the Authors of War ando n enforcement of penalties 83, de 1919, o status de norma internacional consuetudinária, pois "The binding character of customary international law is not only based on state practice, but also evidenced by states' intentions to be bound by certain practices, opinio juris". BASSIOUNI, M. Cherif. Crimes against humanity: historical evolution and contemporary application, Cambridge: Cambridge University Press, 2011, pp. xi/xxvii-xix.
} 
Investimento são singulares nesse sentido ${ }^{43}$, dando azo àquilo que a doutrina tem denominado de fragmentação, e que tem suscitado não poucas desventuras teórico-práticas para a manutenção dos princípios da unidade e da coerência no contexto do ordenamento jurídico internacional ${ }^{44}$, mormente nas hipóteses de conflitos normativos entre self-contained regimes, em que os usuais critérios da especialidade e da cronologia não operam efeitos concretos na solução das antinomias. ${ }^{45}$

Há de se destacar, no entanto, que aquilo que se sente contemporaneamente como uma característica das intersecções entre Direito Nacional e Direito Internacional em áreas do Direito Público - o Direito Penal e os Direitos Humanos são exemplos pujantes dessas intersecções - já era anteriormente experimentado no âmbito do Direito Privado, que foi o primeiro e mais importante laboratório desse fenômeno, conforme apontado por Jacob Dolinger ao discorrer sobre os fenômenos do direito uniforme e o direito uniformizado (também denominado de direito uniforme dirigido ${ }^{46}$.

Pois bem. Os diversos modos pelos quais o Direito Nacional e o Direito Internacional se intersectam nessa complexa tessitura normativa denominada de internacionalizações do direito - a alusão à rede de Indra satisfaz plenamente a realidade dessa estrutura normativa - se manifestam, conforme Mireille Delmas-Marty ${ }^{47}$, a partir de três formas, sempre operadas através do Direito Internacional, a saber:

1. Unificação: trata-se da hipótese identificada por Jacob Dolinger sob a rubrica do direito uniformizado (ou direito uniforme espontâneo), pelo qual os Estados ajustam um tratamento unificado de determinados institutos jurídicos que deverão ser regulados em âmbito interno de conformidade com o regramento estabelecido pelo Direito Internacional;

2. Uniformização: busca estabelecer um tratamento uniforme a determinados institutos jurídicos no bojo dos ordenamentos estatais, que deverão, conforme a sua cultura jurídica e os seus princípios fundamentais, dar eficácia interna às normas internacionais. Nesse sentido, é comum que os tratados internacionais, diversamente do que ocorre na unificação, regule a matéria através de princípios ou regras gerais que permitam aos Estados adequar as suas legislações ao regramento internacional.

\footnotetext{
${ }^{43}$ GOUVEIA, Jorge Bacelar. Manual de Direito Internacional público, Rio de Janeiro: Renovar, 2005, pp. 17-27.

${ }^{44}$ VARELLA, Marcelo D., DE OLIVEIRA, Vitor Eduardo Tavares. Da unidade à fragmentação do Direito Internacional: o caso mox plant. Revista da Faculdade de Direito da UFMG, Belo Horizonte, n. 54, jan-jun/2009, pp. 119-140.

${ }^{45}$ Por todos, KOSKENNIEMI, Martti. Fragmentation of international law: difficulties arising from the diversification and the expansion of International Law - Report of the Study Group of the International Law Commission. INTERNATIONAL LAW COMMISSION, Fifty-eighth session, Geneva, 1 May-9 June and 3 July-11 August 2006.

${ }^{46}$ DOLINGER, Jacob. Direito Internacional privado: parte geral, 6 ed., Rio de Janeiro: Renovar, 2001, pp. 33-42. Conforme este autor, o direito uniforme ocorre quando um Estado recepciona, total ou parcialmente, normas vigentes no ordenamento jurídico de outro Estado; já o direito uniformizado, ou direito uniforme dirigido, decorre do "[...] esforço comum de dois ou mais Estados no sentido de uniformizar certas instituições jurídicas, geralmente por causa de sua natureza internacional” (p. 35).
} 
É o que se dá, geralmente, no âmbito das regulações internacionais sobre o Direito Penal, na medida em que os tratados internacionais, estabelecendo, e.g., mandados internacionais de tipificação interna, o fazem a partir de regras gerais, salvaguardando aos Estados Partes a possibilidade de adotarem integral ou parcialmente o programa internacional a depender dos princípios fundamentais de seus ordenamentos jurídicos ${ }^{48}$.

Um exemplo dentre os muitos, se verifica nas convenções sobre desaparecimento forçado de pessoas. Tanto os artigos 4ㅇ, $7^{\circ}$ e $8^{\circ}$ da Convenção Internacional para a Proteção de Todas as Pessoas Contras os Desaparecimentos Forçados ${ }^{49}$, como os artigos $1^{\circ}$, b e d, $3^{\circ}$ e $7^{\circ}$ da Convenção Interamericana sobre Desaparecimentos Forçados de Pessoas ${ }^{50}$ estabelecem a obrigação internacional de os Estados Partes tipificarem o crime em seus ordenamentos jurídicos, respeitados, de um lado, conteúdos comuns mínimos para a criminalização, e de outro, o respeito aos princípios jurídicos fundamentais de seus ordenamentos jurídicos.

Isto fica muito evidente, v.g., no tocante à imprescritibilidade ou não do delito, já que para o Direito Internacional, sendo o crime de desaparecimento forçado de pessoas uma modalidade de crime contra a

\footnotetext{
${ }^{47}$ DELMAS-MARTY, Mireille.. Trois défis pour un droit mondial, Paris: Éditions du Seuil, 1998, p. 118 et seq.

${ }^{48}$ Basta pensar que um tratado multilateral deverá apresentar parâmetros de regulamentação pelo direito nacional para Estados participes de famílias jurídicas tão dispares como o são os do sistema romano-germânico, anglo-saxão, islâmico, dentre outros, donde o papel importantíssimo desempenhado pelo direito comparado na compreensão do Direito Penal Internacional, mormente no tema relativo aos "princípios gerais do direito penal". Por todos, AMBOS, Kai. A parte geral do Direito Penal Internacional: bases para uma elaboração dogmática, trd. Carlos E. A. Japiassú e Daniel A. Raizman, São Paulo: RT, 2008, pp. 4752. O tema será aprofundado nos capítulos subsequentes.

49 "Artigo 4 - Cada Estado Parte tomará as medidas necessárias para assegurar que o desaparecimento forçado constitua crime em conformidade com o seu direito penal [...] Artigo 7 - 1. O Estado Parte fará com que o crime de desaparecimento forçado seja punível mediante penas apropriadas, que considerem a extrema gravidade desse crime. 2. Os Estados Partes poderão definir: a) Circunstâncias atenuantes, especialmente para pessoas que, tendo participado do cometimento de um desaparecimento forçado, efetivamente contribuam para a reaparição com vida da pessoa desaparecida, ou possibilitem o esclarecimento de casos de desaparecimento forçado, ou a identificação dos responsáveis por um desaparecimento forçado; b) Sem prejuízo de outros procedimentos penais, circunstâncias agravantes, especialmente em caso de morte da pessoa desaparecida ou do desaparecimento forçado de gestantes, menores, pessoas com deficiência ou outras pessoas particularmente vulneráveis [...] Artigo 8 Sem prejuízo do disposto no Artigo 5, 1. O Estado Parte que aplicar um regime de prescrição ao desaparecimento forçado tomará as medidas necessárias para assegurar que o prazo da prescrição da ação penal: a) Seja de longa duração e proporcional à extrema seriedade desse crime; e b) Inicie no momento em que cessar o desaparecimento forçado, considerando-se a natureza contínua desse crime. 2. Cada Estado Parte garantirá às vítimas de desaparecimento forçado o direito a um recurso efetivo durante o prazo de prescrição." 50 "Artigo 1o - Os Estados Membros nesta Convenção comprometem-se a: [...] b) Punir, no âmbito de sua jurisdição, os autores, cúmplices e encobridores do delito do desaparecimento forçado de pessoas, bem como da tentativa de prática do mesmo. [...] d) Tomar as medidas de caráter legislativo, administrativo, judicial ou de qualquer outra natureza que sejam necessárias para cumprir os compromissos assumidos nesta Convenção [...] Artigo $3^{\circ}$ - Os Estados Membros comprometem-se a adotar, de acordo com seus procedimentos constitucionais, as medidas legislativas que forem necessárias para tipificar como delito o desaparecimento forçado de pessoas e a impor-the a pena apropriada que leve em conta sua extrema gravidade. Esse delito será considerado continuado ou permanente, enquanto não se estabelecer o destino ou paradeiro da vítima. Os Estados Membros poderão estabelecer circunstâncias atenuantes para aqueles que tiverem participado de atos que constituam desaparecimento forçado, quando contribuam para o aparecimento com vida da vítima ou forneçam informaçôes que permitam esclarecer o desaparecimento forçado de uma pessoa [...] Artigo $70^{\circ}$ A ação penal decorrente do desaparecimento forçado de pessoas e a pena que for imposta judicialmente ao responsável por ela não estarão sujeitas a prescrição. No entanto, quando existir uma norma de caráter fundamental que impeça a aplicação do estipulado no parágrafo anterior, o prazo da prescrição deverá ser igual ao do delito mais grave na legislação interna do respectivo Estado Membro."
} 
humanidade, é imprescritível ${ }^{51}$, o mesmo não o sendo para os Estados que, nos termos das duas convenções, adotem o regime de prescrição (artigos $7^{\circ}$ e $8^{\circ}$ dos respectivos tratados internacionais). Assim, como forma de uniformizar a temática em âmbito interno, as duas convenções estabelecem: que a prescrição seja correspondente aos crimes mais graves existentes nos ordenamentos nacionais e que o prazo prescricional somente inicie a partir do momento em que o delito se consumar (com o retorno da pessoa ou a descoberta de seu paradeiro ou corpo), dado o seu caráter permanente (que é um critério comum de criminalização para todos os ordenamentos jurídicos).

3. Harmonização: nessa hipótese, por fim, busca-se, na melhor medida do possível, uma harmonia entre o que é assegurado internacionalmente e aquilo que é vivido em âmbito nacional em termos de valores e princípios jurídicos fundamentais das mais diversas nações.

Trata-se, portanto, da constatação da impossibilidade de uniformização e pela busca de um compromisso internacional que permita um grau mínimo de coesão acerca de determinada matéria, servindo-se o Direito Internacional, mais uma vez, de mandados de internalização das matérias mediante regras e princípios gerais $^{52}$.

Pois bem. O tema de que cuida o presente trabalho é uma clara expressão do fenômeno da internacionalização do direito, em especial na problemática relação entre Direito Penal e Direito Internacional dos Direitos Humanos, caracterizado, seja do ponto de vista teórico seja do ponto de vista prático, por não poucas contradições, e que tendem, se expressadas na forma de uma absolutização dos princípios da segurança ou da liberdade, numa verdadeira aporia.

Ora, tanto o Direito Penal como o Direito Internacional dos Direitos Humanos, conforme já afirmado, representam campos de regulação jurídica que inicialmente se concentravam na esfera de normatização estatal e que têm passado, desde o primeiro quartel do século XIX por uma progressiva internacionalização, primeiro o Direito Penal, e depois os Direitos Humano.

No contexto do Direito Penal, M. Cherif Bassiouni ${ }^{53}$, em um estudo no qual ele apresenta o desenvolvimento histórico e a prática contemporânea do princípio da jurisdição universal, afirma que em 2001 haviam 276 tratados internacionais, celebrados entre os anos de 1815 e 1999, e que definiam 27 espécies de crimes ( $v$ g., crimes contra a humanidade, agressão, genocídio, tráfico internacional de pessoas ou de substâncias

\footnotetext{
${ }^{51}$ Nesse sentido, artigo 29 do ETPI. Na mesma senda, Resolução 2338 (XXII), da Assembleia Geral das Nações, de 18 de dezembro de 1967 e a Convenção sobre a Imprescritibilidade dos Crimes de Guerra e dos Crimes Contra a Humanidade, de 26 de novembro de 1968.

52 Sobre esta temática em particular, ver o Capítulo 8, no qual se discute a internacionalização do direito da execução penal a partir do problema da harmonização.

${ }^{53}$ BASSIOUNI, M. Cherif. "Universal jurisdiction for international crimes: historical perspectives and contemporary practice". Virginia Journal of International Law 42, n. 81, fall 2001.
} 
estupefacientes, terrorismo internacional, pirataria etc), estabelecendo, a partir de critérios variados, a jurisdição universal dos Estados, ou a extraditabilidade ou mesmo uma combinação de ambos (princípio aut dedere aut judicare) para a persecução penal desses delitos (indirect enforcement). Já no âmbito do Direito Internacional Costumeiro, afirma que o crime de pirataria se constitui na primeira forma de incriminação internacional. Aponta, ademais, o próprio desenvolvimento da jurisdição das Cortes Internacionais, de Nuremberg e Tóquio ao TPI, como expressão da crescente preocupação da sociedade internacional no enfrentamento dos Core Crimes a partir de um postulado claramente humanitário, e não mais egoístico dos Estados, em que a própria sociedade internacional, através de órgãos próprios, exerce a persecução penal em relação a estes crimes (sistema direct enforcement $\left.{ }^{54}\right)$.

Já com relação aos Direitos Humanos, Norberto Bobbio ${ }^{55}$ indica as três viragens históricas por que passou a regulação da matéria: a) primeiramente, entre os séculos XVIII e início do século XX, os direitos humanos foram assegurados quase que exclusivamente através de normas nacionais - constitucionais ou não, sendo a hipótese do nascente Direito Internacional Humanitário uma exceção a este fenômeno ${ }^{56}$; b) a partir do entre guerras e o fim da segunda guerra mundial, a crescente internacionalização dos direitos humanos, mormente a partir da Declaração Universal dos Direitos do Homem de 1948 e dos Pactos Internacionais de 1966, dentre outros tratados internacionais de caráter universal e regional e c) na constitucionalização, pelas Constituições democráticas do pós-segunda guerra mundial, dos Direitos Humanos assegurados em documentos internacionais, passando a existir quase que uma identidade textual entre os dispositivos internacionais e nacionais, embora, como era de se esperar, não se tenha o mesmo efeito no contexto da aplicação/interpretação desses direitos.

Dado o que se disse até agora, seria possível caracterizar-se a internacionalização do Direito Penal da seguinte forma: tanto a competência legislativa do Estado como o exercício de seu poder persecutório em relação ao fenômeno criminal está, em graus bastante variados, vinculado ${ }^{57}$ ao sistema internacional de cooperação

\footnotetext{
${ }^{54}$ BASSIOUNI, M. Cherif. Introduction to international criminal law, [s.ed], New York: Transnational Publishers, 1997, p. 333 et seq.

${ }^{55}$ BOBBIO, Norberto. A era dos direitos, 9 ed., trad. Carlos N. Coutinho, Rio de Janeiro: Campus, 2004, p. 45 et seq; BOBBIO, Noberto. POLITO, Pietro (Org.). O terceiro ausente: ensaios e discursos sobre a paz e a guerra, trd. Daniela Versiani, Barueri: Manole, 2009, p. 111 et seq.. Para uma análise do caso brasileiro, MAGALHÃES, José Luiz Quadros de. Direito constitucional, T. I, Belo Horizonte: Mandamentos, 2000, p. 46 et seq.

${ }^{56}$ Mesmo porque, não se pode falar propriamente de Direito Internacional dos direitos humanos antes do surgimento do Direito Internacional humanitário na Convention for the amelioration of the conditions of the wounded in armies in the field, dita de Genebra, de 1864, e que foi seguida pela Declaration renouncing the use, in time of war, of explosive projectiles under 400 grammes wieght, dita de São Petersburgo, de 1868, e no entre guerras, de algumas normas internacionais de proteção às minorias e a constituição, no Tratado de Versalhes, da Organização Internacional do Trabalho.

${ }^{57}$ Por vinculação se há de compreender que os Estados, ao ratificarem um Tratado Internacional, estão obrigados a lhe darem cumprimento em atenção aos princípios pacta sunt servada e bona fide (artigo 26 c/c artigo 29 da Convenção de Viena sobre Direito dos Tratados entre Estados de 1969 (doravante CVDTE/69)). Isto implica, em ligeira síntese, no dever jurídico de agir
} 
internacional em matéria penal, sejam eles de caráter universal através das diversas Convenções Internacionais pactuadas na ONU, seja de caráter regional, no âmbito, e.g., da União Europeia e da Organização dos Estados Americanos ${ }^{58}$, dos quais derivam obrigações de natureza legislativa, administrativa e judicial, como, v.g., o dever de tipificação de comportamentos, a cooperação judiciária e policial entre Estados no âmbito, por exemplo, da extradição, a persecução penal etc.

Referida internacionalização é consequência da reiteração de obrigações internacionais ratificadas pelos Estados em matéria penal, na qual prepondera o liame cada vez mais estreito entre jurisdições nacionais e internacionais, em especial no âmbito dos core crimes, mormente em razão do princípio da complementariedade, tal como estabelecido no parágrafo 10 e nos artigos 1 e 17 do ETPI.

Conforme William A. Schabas ${ }^{59}$, o princípio da complementariedade

Como originalmente concebido, o termo "complementariedade" pode ser um pouco ambíguo, pois o que se estabelece é uma relação entre a justiça nacional e a justiça internacional na qual esta está longe de ser "complementar". Em vez disso, os dois sistemas funcionam em oposição e, em certa medida, com hostilidade via-à-viso outro.

O conceito é muito diferente do regime estabelecido para os tribunais ad hoc, conhecido por primazia, segundo o qual os tribunais ad hoc ${ }^{60}$ podem assumir a jurisdição de direito, sem a necessidade de demonstrar a falha ou insuficiências do sistema nacional. Ele é mais análogo à abordagem adotada por organismos internacionais de direitos humanos, que exigem do reclamante ou peticionário demonstrar o esgotamento dos recursos internos. Os sistemas nacionais têm prioridade em termos de resolução de seus próprios problemas de direitos humanos, e só quando eles deixarem-no de fazer, os organismos internacionais poderão prosseguir. Provavelmente, a maior parte das petiçōes internacionais são recusadas nessa fase por falta de esgotamento dos recursos internos.

É importante destacar, entretanto, que os princípios da complementariedade e da primazia não são os únicos a reger a jurisdição penal em matéria de persecução dos crimes internacionais, na medida em que também

conforme o que foi pactuado no Tratado Internacional, devendo-se, por regra geral, adequar o seu ordenamento jurídico aos termos daquela obrigação, de acordo com os princípios gerais e cultura jurídica do Estado. Nenhuma regra de direito interno, seja qual for a sua posição na hierarquia das fontes (isto para os ordenamentos jurídicos dotados de, pelo menos, constituições rígidas) poderá servir de escusa para o inadimplemento da obrigação livremente assumida (artigo 27 da CVDTE/69).

${ }^{58}$ Exemplo importante nesse sentido é a Convenção Interamericana sobre o Desaparecimento Forçado de Pessoas, de 1994, em seu artigo $1^{\circ}, \mathrm{b}$ e d c/c artigos $3^{\circ} \mathrm{e} 4^{\circ}$. Esta Convenção encontra-se em processo de ratificação, já tendo sido aprovada pelo Congresso Nacional através do Decreto Legislativo n. 127/2011.

${ }^{59}$ SCHABAS, William A. An introduction to the International Criminal Court, 4 ed., Cambridge: Cambridge University Press, 2011,pp. 190-191.

${ }^{60} \mathrm{O}$ autor faz referência aos Tribunais Internacionais para Ex-Iugoslávia e para Ruanda, que em seus respectivos Estatutos estabeleciam o princípio da primazia de suas jurisdições sobre as jurisdições dos Estados nacionais, conforme, respectivamente, os artigos $1^{\circ} \mathrm{e} 9,1$ do Estatuto do Tribunal Penal Internacional para a Ex-Iugoslávia (doravante ETPIExlug), de 25 de maio de $1993 \mathrm{e}$ os artigos $1^{\circ}$ e 8, 1 do Estatuto do Tribunal Penal Internacional para Ruanda (ETPIR), de 08 de novembro de 1994. No mesmo sentido BAZELAIRE, Jean-Paul, CRETIN, Thierry. A justiça penal internacional: sua evolução, seu futuro de Nuremberg a Haia, trd. Luciana P. Venâncio, Bauru: Manole, 2004, pp. 95-97. Sobre os referidos Tribunais ad hoc consultar as excelentes monografias de HAGAN, John. Justice in the Balcans: prosecuting war crimes in the Hague Tribunal, Chicago: Chicago University Press, 2003, no qual o autor destaca o papel desempenhado por M. Cherif Bassiouni em todo o processo de investigação dos crimes praticados na guerra dos Balcans e no da criação do tribunal, com especial enfoque no tema relativo ao litígio político-discursivo entre defensores da justiça internacional e realpolitik, dentre outros; e CRUVELLIER, Thierrry. Court of remorse: inside the 
se reconhece a regra da concorrência no âmbito do princípio da justiça universal ou cosmopolita ${ }^{61}$. Por meio dessa forma de jurisdição penal internacional, qualquer Estado que tenha assumido a obrigação internacional ${ }^{62}$ de exercer a persecução penal em relação aos crimes internacionais, próprios ou impróprios, será competente para julgar, conforme o seu próprio ordenamento jurídico, aos autores que os tenham praticado fora da esfera de validade de sua jurisdição penal ${ }^{63}$, tendo em vista a regra de conexão ${ }^{64}$ prevista para estes crimes, a incriminação internacional ${ }^{65}$, jurisdição essa que cede passo somente se o Estado territorialmente competente exerceu ou vir a exercer a persecução penal ${ }^{66}$.

Frise-se, no entanto, que após a decisão proferida pela CIJ no caso Yerodia ${ }^{67}$, o tema relativo à jurisdição universal dos Estados em relação aos crimes internacionais foi significativamente modificado, mormente no que diz respeito à reafirmação das imunidades diplomáticas e dos limites internacionais ao exercício dessa forma de

International Criminal Court for Rwanda, trd. Chari Voss, Madison: University of Wisconsin Press, 2006.

${ }^{61}$ Esse foi um dos argumentos utilizados pelo Tribunal Constitucional da Espanha, por intermédio de sua Sala Segunda, quando julgou procedente o juízo de amparo proposto por Rigoberta Menchú e outros em face às decisões proferidas pelo Pleno da Sala Penal da Audiência Nacional, mantida pela Segunda Sala do Tribunal Supremo de Justiça, que haviam determinado o arquivamento do processo de investigação aberto pela Audiência Nacional em razão dos crimes de tortura, genocídio e outros crimes internacionais ocorridos na Guatemala entre os anos de 1978 e 1986. TRIBUNAL CONSTITUCIONAL DE ESPAÑA. Sala Segunda. Sentencia 237/2005, de 26 de septiembre. Recursos de amparo 1744-2003,1755-2003 y 1773-2003 (acumulados). Promovidos por doña Rigoberta Menchú Tumn y otros frente a la Sentencia y Auto de las Salas de lo Penal del Tribunal Supremo y de la Audiencia Nacional, en causa por delitos de

genocidio, terrorismo y torturas en Guatemala. Vulneración del derecho a la tutela judicial efectiva (acceso a la justicia penal): jurisdicción universal de los Tribunales españoles en materia penal. BOE n. 258 - Suplemento, Viernes 25/10/2005.

${ }^{62}$ Assunção esta que pode derivar de norma convencional ou consuetudinária. JANKOV, Direito Internacional penal..., p. 100.

${ }^{63}$ Nesse sentido, é importante diferençar a esfera de validade da esfera de eficácia. A esfera de validade será, sempre, o território do Estado, real ou por ficção. Já a esfera de eficácia é a possibilidade de se aplicar as normas nacionais a atos ou fatos ocorridos fora do território, o que dá azo ao princípio da extraterritorialidade. Conforme Hildebrando Accioly: "O primeiro é aquele no qual o Estado executa, ou aplica, com exclusividade, suas próprias normas. A esfera de eficácia é mais extensa, sendo, por assim dizer, ilimitada [...]" como, $v$ g., no caso da competência pessoal do Estado, "[...] que alcança [...] nacionais seus, que se encontram fora da esfera própria de validade de suas competências. Em tais casos, o que ocorre não é a extensão da validade da ordem jurídica do Estado [...] é, sim, apenas, a extensão da eficácia das normas jurídicas do primeiro a indivíduos que a ele se acham ligados [...]. Essa eficácia também se exerce [...] em relação a navios e aeronaves fora de seu espaço marítimo ou de seu espaço aéreo". ACCIOLY, Hildebrando. Tratado de Direito Internacional público, vol. II, 3 ed., São Paulo: Quartier Latin, 2009, p. 156.

64 "As regras de conexão são as normas estatuídas pelo D.I.P. que indicam o direito aplicável às diversas situações jurídicas conectadas a mais de um sistema legal". DOLINGER, Direito Internacional privado..., p. 289.

${ }^{65} \mathrm{JANKOV}$, Direito Internacional penal..., pp. 100-102.

${ }^{66}$ Collhe-se o seguinte trecho da decisão do Tribunal Constitucional espanhol nos autos do Sentença 237/2005: "El principio de subsidiariedad no aparece recogido en nuestro Derecho positivo, ni en la LOPJ ni en el Convenio sobre genocidio, que efectivamente no prohíbe la jurisdicción universal respecto de ese delito, existiendo de hecho diversos países que la han establecido en sus legislaciones. La jurisdicción universal «no se rige por el principio de subsidiariedad, sino por el de concurrencia, pues precisamente su finalidad es evitar la impunidad», aplicándose el principio de no necesidad de intervención cuando está actuando la jurisdicción territorial. Esto no faculta para exigir la acreditación plena de la inactividad de dicha jurisdicción territorial para admitir la querella, sino la aportación de indicios razonables de que los crímenes denunciados no han sido hasta la fecha perseguidos de modo efectivo, lo que se desprende en este caso de la documentación aportada. Por ello la estimación del recurso de casación en relación con la aplicación del principio de subsidiariedad debió determinar la admisión de la querella en los términos del Auto dictado por el Juzgado Central, y puesto que la subsidiariedad constitúa la única fundamentación del Auto de la Sala de la Audiencia Nacional, que es considerada incorrecta por la mayoría, lo consecuente habría sido casar el Auto recurrido."

${ }^{67}$ INTERNATIONAL COURT OF JUSTICE. Yerodia Case, disponível em http://www.icj-cij.org/docket/files/121/7081.pdf. 
persecução criminal - vedando, por exemplo, a jurisdição internacional in absencia.

A ideia expressada por William A. Schabas de uma hostilidade vis-à-vis entre as jurisdições nacionais e a do TPI, e que pode ser estendida às relações entre jurisdições estatais quanto ao exercício do princípio da jurisdição universal, põe em relevo um tema que precisa ser discutido nesse trabalho, que é o da (in)existência de um conflito real entre soberania nacional e os institutos do Direito Penal Internacional, o que será enfrentado no próximo item.

\section{INTERNACIONALIZAÇÃO DO DIREITO PENAL E O PROBLEMA DA SOBERANIA}

Não parece existir um tema mais polêmico no plano das relações entre Direito Nacional e Direito Internacional do que o relativo à soberania ${ }^{68}$, polêmica que opõe em polos distintos soberanistas e internacionalistas e que parece excluir uma via conciliatória, bastando lembrar, para fins de pontuação, a oposição entre monistas ${ }^{69}$ e dualistas ${ }^{70}$ no que diz respeito às relações entre Direito Internacional e Direito Interno.

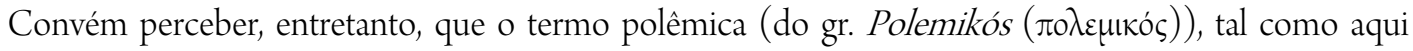

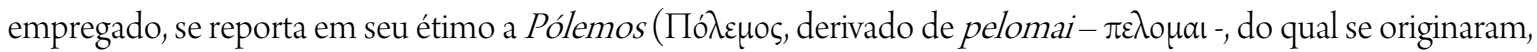
por exemplo, to bustle, alvoroço, controvérsia etc) - que originalmente indicava ao daimon da guerra e da discórdia, e que por derivação metonímica, passou a nomear o próprio fato da discórdia, da guerra.

Faz-se essa digressão linguística para pôr em questão o próprio fato de sua origem, e que somente pode ser encontrada no âmbito da discórdia discursiva entre soberanistas e internacionalistas, e que resta melhor compreendida ao se utilizar de um referencial da teoria crítica. No presente trabalho, este referencial será a fase genealógica de Michel Foucault.

Pois bem. Michel Foucault nesta fase de sua obra, também conhecida por analítica do poder, ao abdicar de uma análise formal-substancialista para a compreensão dos problemas da filosofia política - O que é o poder? O que é a soberania? O que é o direito? etc -, adota um procedimento no qual ele passou a perquirir sobre o "como do poder" ${ }^{11}$ :

\footnotetext{
Acessado em 25/07/2012, às 10:00:00.

68 "Uma palavra que se repete frequentemente nos escritos dos seguidores de Vattel é "soberania", e é duvidoso que qualquer outra palavra tenha causado tanta confusão intelectual e conflito [lawlessness] internacional”. AKERURST, Michael, MALANCZUK, Peter (org.). Akehurt's modern introduction to internacional law, 17 ed., New York: Routledge, 1997, p. 17.

${ }^{69}$ KELSEN, Hans. Les rapports de sytème entre le Droit Interne et le Droit International, RCADI vol 14, pp. 227-332, 1926.

${ }^{70}$ TRIEPEL, H. Les rapports entre le Droit Interne et le Droit International, RCADI vol 1, pp. 73-122, 1923.

${ }^{71}$ FOUCAULT, Michel. Soberania e disciplina, in Microfísica do poder, 23 ed., trad. Maria Teresa de Oliveira e Roberto Machado, São Paulo: Graal, 2007, p. 179/181.
} 
O que tentei investigar [...] foi o como do poder; tentei discernir os mecanismos existentes entre dois pontos de referência, dois limites: por um lado, as regras do direito que delimitam formalmente o poder e, por outro, os efeitos de verdade que este poder produz, transmite e que por sua vez reproduzem-no. [...] A questão fundamental da filosofia política poderia ser esquematicamente formulada nesses termos: como pode o discurso da verdade [...] fixar os limites de direito do poder? Eu preferiria colocar uma outra, mais elementar e muito mais concreta em relação a esta pergunta tradicional [...]: de que regras de direito as relações de poder lançam mão para produzir discursos de verdade? [...] Afirmar que a soberania é o problema central do direito nas sociedades ocidentais implica, no fundo, dizer que o discurso e a técnica do direito tiveram basicamente a função de dissolver o fato da dominação dentro do poder $[\ldots]$.

Assim, a perquirição pelo "como do poder" se constitui no método que permitiu a Michel Foucault apreender um ponto central que media dois polos distintos: num polo, as regras de direito que delimitam formalmente o poder a partir do discurso da soberania; noutro polo, aquilo que ele denominava por efeitos de verdade produzidos pelo poder, isto é, a criação de subjetividades. É, portanto, entre esses dois polos que o poder é exercido $^{72}$ - e não constituído - já que o poder não tem uma essência, uma substância, mas somente existe em ato - a tríade direito, poder e verdade. Como já afirmado em outro local ${ }^{73}$ :

A singularidade da obra de Michel Foucault em relação àquelas outras que se fundaram e se fundam numa análise substancialista do poder é a de demonstrar, a partir de uma abordagem que ele denominava de acontecimentalização, a relação indissociável entre o poder e os discursos de verdade das mais diversas ciências como forma de legitimar o exercício do poder; que não existe poder sem saber; que não existe saber sem poder. A conhecida díade poder-saber.

O poder não seria exercido se não fosse posto em circulação por um saber, isto é, por um discurso de verdade que funciona como estratégia ao seu exercício sobre indivíduos ou sobre uma população, aos quais incute uma verdade e que os obriga a proferir esta verdade e a viver segundo esta verdade, de modo a tornar possível a dominação irrefletida. Contudo, o saber também não existiria sem o poder. A função do poder em Michel Foucault não é somente o de propiciar a dominação, como também o de fazer circular um saber que tem a finalidade de lhe dar legitimidade. Muito mais do que produzir ou formar um saber, o poder sustenta um saber de que necessita para ser exercido de forma inconteste.

Uma vez tendo caracterizado o poder como acontecimento ${ }^{74}$ é que Michel Foucault poderá inverter o famoso aforismo de Carl von Clausewitz - “a guerra é a continuação da política por outros meios” -, substituindoa por uma concepção bélica da política, segundo a qual - "a política é a continuação da guerra por outros meios"75 -, na medida em que os discursos sobre a verdade desempenham um papel preponderante para o exercício

\footnotetext{
${ }^{72}$ FOUCAULT, Em defesa da sociedade, p. 28.

${ }^{73}$ DE OLIVEIRA, Guerra ao terror..., p. 31.

${ }^{74}$ Para uma melhor explicação sobre o conceito de acontecimentalização, consultar FOUCAULT, Michel. O que é a crítica? Crítica e Aufklärung, trad. Gabriela Lafetá Borges, disponível em http://www.unb.br/fe/tef/filoesco/foucault/, acessado em 15 de fevereiro de 2006, às 3:00:00.

${ }^{75}$ FOUCAULT, Em defesa da sociedade, p. 22. É óbvio que a teoria foucautiana na sua fase analítica não se encerra na caracterização bélica da política, já que a mesma tem por finalidade fundamentar a sua originalíssima concepção sobre a biopolítica, com a qual ele demonstra o caráter econômico da política moderna, a assunção da própria vida biológica do homem como meta
} 
concreto do poder. A pólemos, portanto, não se dá mais no corpo-a-corpo dos campos de batalha, mas na esfera discursiva em que os saberes se debatem vis-à-vis para justificar o exercício do poder e ocultar o fato da dominação.

É a partir desse referencial teórico que se irá interpretar a polêmica entre soberanistas e internacionalistas.

\section{Jurisdição Penal Internacional e Soberania}

Para expressar claramente a polêmica no concernente à justiça penal internacional, vejamos um diálogo narrado por Antonio Cassesse com um parlamentar de um Estado europeu logo após a criação do Tribunal Penal Internacional para a Ex-Iugoslávia - do qual ele foi o primeiro presidente - e que demonstra à saciedade esse litígio discursivo. Disse o parlamentar a Antonio Cassesse ${ }^{76}$ :

As Comunidades Europeias estão expropriando nosso poder legislativo! E agora, vocês vêm, com esse Tribunal Internacional, retirar-nos o último bastião de nossa soberania: o poder de punir. Se as coisas continuarem assim, o Estado soberano acabará por se dissolver.

Mas o mesmo se passa na seara dos penal-internacionalistas, conforme, jocosamente, expressa Robert Cryer ${ }^{77}$ :

Quando a soberania aparece na área de estudo do Direito Internacional penal, comumente vem vestida com chapéu e capa. Um cheiro de enxofre permeia o ar. Geralmente os estudiosos do Direito Penal Internacional vêm a soberania como inimiga. Ela é vista como irmã da realpolitik, frustrando a justiça penal internacional em cada rodada.

Pois bem. Assim como afirmam Antonio Cassesse, Robert Cryer, M. Cherif Bassiouni ${ }^{78}$ e Allison Marsten Danner e Beth Simmons ${ }^{79}$, dentre outros autores, interpreta-se nesse trabalho que esse litígio mais do que envolver um problema jurídico sobre a soberania, envolve um problema político sobre os limites internacionais de atuação do Estado, bem como dos custos político-jurídicos envolvidos na cooperação internacional, em especial no tema concernente à persecução penal aos core crimes.

Essa interpretação leva em conta pelo menos três fundamentos:

última do exercício do poder, a possibilidade de esta biopolítica se converter numa tanatopolítica etc.

${ }^{76}$ CASSESSE, Antonio. Existe um conflito insuperável entre soberania dos Estados e justiça penal internacional?, in CASSESSE, Antonio, DELMAS-MARTY, Mireille (Orgs.). Crimes internacionais e jurisdições internacionais..., p. 3.

${ }^{77}$ CRYER, Robert. International Criminal Law vs State Sovereignty: Another Round? The European Journal of International Law vol. 16, n. 5, 2006.

${ }^{78}$ BASSIOUNI, M. Cherif. The perennial conflict between international criminal justice and realpolitik, $38^{\text {th }}$ Henry J. Miller Distinguished Lecture, Georgia State University College of Law, disponível em http://law.gsu.edu/Miller_Lecture/2006/MillerLecture-S06-BassiouniDraft.pdf, acessado em 15/05/2012, às 15:45:00.

${ }^{79}$ DANNER, Allison Marsten, SIMMONS, Beth. Sovereignty costs, credible commitments, and the International Criminal Court. Disponível em www.law.yale.edu/documents/pdf/Faculty/DannerSimmons07.pdf, acessado em 10/06/2013, às 17:00:00 
1. primeiro, juridicamente falando, a soberania sempre foi assegurada e delimitada pelo Direito Internacional e, segundo a melhor doutrina ${ }^{80}$, nunca se referiu às relações entre o direito nacional e o Direito Internacional, mas somente às relações entre Estados ${ }^{81}$;

2. segundo, o problema, sendo político, é encontrado não no contorno jurídico-internacional da soberania, mas na realpolitik; e

3. terceiro, de fato, a contínua institucionalização da justiça internacional tende a diminuir não a soberania dos Estados, mas a exclusividade de sua jurisdição penal em relação aos crimes internacionais, o que, de resto, acontece em outras áreas do direito.

Quanto ao primeiro critério, é importante desambiguizar o conceito de soberania na perspectiva do Direito Internacional.

É sabido que o conceito de soberania é subdividido em duas manifestações autônomas, mas complementares, a saber, soberania interna e soberania externa.

A primeira, regida internacionalmente pelo princípio da não intervenção em assuntos de jurisdição interna, assegura aos Estados, no exercício de suas competências político-jurídicas de autoconstituição, autoorganização e autogoverno, se organizarem político-juridicamente de conformidade com a ideia de direito ${ }^{82}$ que for soberanamente decidida por seu povo através de suas Constituições e leis. Em outras palavras, sistema político, regime e forma de governos, distribuição de competências entre os órgãos de soberania, delimitação da atuação de suas respectivas ações tanto entre órgãos como, principalmente, em relação aos indivíduos (Direitos

\footnotetext{
${ }^{80}$ Esta é a concepção que se pode recolher entre os clássicos do Direito Internacional moderno: BODINO, Juan. Los seis libros de la Republica, t. I, trd. Gaspar de A. Isunza, Madri: Centro de Estudios Constitucionales, 1992, pp. 267 et seq; GROTIUS, Hugo. O direito da guerra e da paz, vol. I, trd. Ciro Mioranza, Ijuí: Editora Unijui, 2044, pp. 175 et. seq;; DE VATTEL, Emer. O direito das gentes, trd. Vicente Marotta Rangel, Brasília: IPRI/Editora da UNB, 2004, pp. 1 et seq. Markus Kotzur chama à atenção para o fato de que a tríade caracterizadora da soberania na obra de Vattel ainda hoje orienta a compreensão da CIJ em sua jurisprudência: "[...] E. de Vattel tencionou fazer uma interpretação ampla da soberania estatal e estabeleceu uma diferenciação com base nas seguintes características: autogoverno, independência de outros Estados e vinculação direta ao Direito Internacional. A tríade de de Vattel marcou, e marca ainda hoje, a doutrina internacional sobre a soberania, a atuação dos Estados e a jurisprudência da Corte Permanente de Justiça Internacional, primeiro, e logo depois da Corte Internacional de Justiça. Consequentemente, um Estado é soberano quando não está submetido a nenhuma autoridade que não seja o Direito Internacional, quando pode adotar decisões obrigatórias últimas sobre os seus súditos em seu território (soberania interna) e quando é independente externamente, longe de todo influxo proveniente de outros Estados". KOTZUR, Markus. A Soberania Hoje. Palavras-Chave para um Diálogo Europeu Latino-Americano Sobre um Atributo do Estado Constitucional Moderno, trd. Marcus V. X. de Oliveira e Gabriel G. de Godói, Revista Quaestio Iuris, Rio de Janeiro, 2012, pp. 1-19.

${ }^{81}$ Conforme Akehurst "[...] a palavras ainda carrega uma tonalidade emotiva de poder ilimitado, acima da lei, e isso deu uma imagem totalmente enganosa das relações internacionais. $\mathrm{O}$ fato de um governante poder fazer o que ele quer em seus próprios assuntos não significa que ele possa fazê-lo, em questões de direito ou de poder político, a outros Estados". AKEHURST, Akehurt's modern introduction ..., p. 17.

${ }^{82}$ MIRANDA, Jorge. Teoria do Estado e da constituição, Rio de Janeiro: Forense, 2002, p. 358/377: "[...] soberania significa faculdade originária de livre regência da comunidade política mediante a instituição de um poder e a definição do seu estatuto jurídico [...] que se identifica por certa origem e finalidade e se manifesta em certas circunstâncias; são os limites ligados à configuração do Estado à luz do poder constituinte material ou à própria identidade do Estado de que cada Constituição
} 
Fundamentais), dentre outros temas, se conformam em assuntos de livre decisão política assegurada internacionalmente pelo princípio da não intervenção, pelo qual nenhum Estado, ou mesmo a sociedade internacional, poderá se imiscuir de forma a sobredeterminar a adoção de um programa político ou o modo como um determinado conflito interno de exclusiva jurisdição do Estado será resolvido, conforme, aliás, expressamente reconhecido pelo artigo 2, 7 da Carta das Nações Unidas (doravante CONU) e artigo $1^{\circ}$ comum aos Pactos Internacionais de Direitos Civis e Políticos e dos Direitos Econômicos, Sociais e Culturais, ambos de 1966 (doravante, PIDCP/66 e PIDESC/66), princípio este que tem sido correntemente reafirmado pela Assembleia Geral das Nações Unidas (doravante ASGNU), como, vg., na Resolução 2625 (XXV), de 24 de outubro de 1970, que proclamou a Declaração sobre os Princípios do Direito Internacional Relativos às Relações de Amizade e de Cooperação entre os Estados em Conformidade com a Carta das Nações Unidas (doravante DPDIRRACE $/ 70) .83$

Agora, uma leitura atenta do artigo 2, 7 da CONU demonstra à saciedade que, aquilo que é denominado soberania em âmbito interno é ali denominado de jurisdição (domestic jurisdiction) (in litteris: "[...] intervirem em assuntos que dependam essencialmente da jurisdição de qualquer Estado [...]”), expressão que, no plano internacional, identifica, conforme Patrick Capps, Malcolm Evans e Stratos Konstadinidis ${ }^{84}$

[...] uma forma de poder legal ou competência. Conforme Hohfeldian, isto significa que a jurisdição diz respeito ao poder de controlar e alterar as relações jurídicas daqueles que estão sujeitos a essa competência através da criação e aplicação de normas jurídicas. Assim, por exemplo, um Legislativo pode promulgar uma série de regras que alterem as relações jurídicas das pessoas que the estão sujeitas (por exemplo, os cidadãos ou empresas). Além disso, os Estados que tenham consentido no exercício da chamada jurisdição obrigatória da CIJ pode ter algumas de suas relações jurídicas julgadas pelo Tribunal, uma vez que tem a competência para determinar os direitos e obrigações dos Estados que tenham consentido em sua jurisdição.

representa apenas um momento da marcha histórica”.

${ }^{83}$ Ao estabelecer os contornos desse princípio, a aludida Resolução assim o faz: "The principle concerning the duty not to intervene in matters within the domestic jurisdiction of any State, in accordance with the Charter - No State or group of States has the right to intervene, directly or indirectly, for any reason whatever, in the internal or external affairs of any other State. Consequently, armed intervention and all other forms of interference or attempted threats against the personality of the State or against its political, economic and cultural elements, are in violation of international law. No State may use or encourage the use of economic political or any other type of measures to coerce another State in order to obtain from it the subordination of the exercise of its sovereign rights and to secure from it advantages of any kind. Also, no State shall organize, assist, foment, finance, incite or tolerate subversive, terrorist or armed activities directed towards the violent overthrow of the regime of another State, or interfere in civil strife in another State. The use of force to deprive peoples of their national identity constitutes a violation of their inalienable rights and of the principle of non-intervention. Every State has an inalienable right to choose its political, economic, social and cultural systems, without interference in any form by another State. Nothing in the foregoing paragraphs shall be construed as reflecting the relevant provisions of the Charter relating to the maintenance of international peace and security."

${ }^{84}$ CAPPS, Patrick, EVANS, Malcolm, KONSTADINIDIS, Stratos (Org.). Asserting jurisdiction: International and European legal approachs, Oxford: Hart Publishing, 2003, pp. xix-xx. No mesmo sentido SHAW, Malcolm. International law, $6^{\text {th }}$ ed., Cambridge: Cambridge University Press, 2008, p. 645: "Jurisdiction concerns the power of the state under international law to regulate or otherwise impact upon people, property and circumstances and reflects the basic principles of state sovereignty, equality of states and non-interference in domestic affairs". 
Assim, o que se denomina de soberania em nível interno é identificado internacionalmente pela expressão jurisdição, expressão esta que abrange o conjunto de competências internacionalmente asseguradas pelo Direito Internacional para que o Estado possa, no gozo de sua independência, conforme Vaugham Lowe "[...] criar, aplicar e executar as regras de conduta aos indivíduos. Relaciona-se essencialmente à extensão do direito do Estado de regular a conduta e as consequências dos eventos" 85 (grifos nossos), ou conforme Celso D. de A. Mello "O Estado tem o direito de exercer sua jurisdição sobre todas as pessoas e coisas no seu território nacional. As restrições à jurisdição estatal são impostas pelo DI"\$6 (grifos nossos).

Ora, estando o conceito de soberania em nível interno ligado ao de poder constituinte originário ${ }^{87}$, será interessante perceber que para a doutrina constitucional de cariz democrática, mesmo reconhecendo que o poder constituinte originário tem por natureza ser um poder político de fato, tendo por características a soberania (ou ilimitabilidade), a incondicionalidade, a latência, a instantaneidade, a inalienabilidade e a especialidade, as mesmas se reportam não ao Direito Internacional, mas antes à ordem jurídica interna anteriormente vigente ou, em sendo o caso de independência, ao ordenamento jurídico da metrópole ${ }^{88}$, e nesta última forma, por incidência do princípio de Direito Internacional da livre determinação dos povos. Trata-se, de qualquer sorte, de um poder limitado, externa ou internamente, e que segundo Jorge Miranda teria três fontes: a primeira de caráter interno (limitações intrínsecas) e que se reportariam à ideia de direito e programa constituinte desencadeador da nova constituição; a segunda de caráter transcendental, e que se reportariam aos valores comuns da comunidade internacional (orientado pelo princípio da dignidade da pessoa humana); e as limitações heterônomas, internas e externas, sendo estas aquelas "[...] provenientes da conjugação com outros ordenamentos jurídicos. Referem-se a princípios, regras ou actos de Direito Internacional, donde resultem obrigações para todos os Estados ou só para certo Estado [...]"; são de caráter geral "[...] os princípios de jus cogens [...] Estruturantes da comunidade internacional, eles não podem deixar de se sobrepor à Constituição de qualquer Estado enquanto membro dessa comunidade”; são de caráter especial “[...] os que correspondem a limitações do conteúdo da Constituição por virtude de deveres assumidos por um Estado para com outro ou outros Estados ou para com a comunidade internacional no seu conjunto" ${ }^{89}$

Desta sorte, recolhendo quer a orientação provinda do Direito Internacional quer do próprio Direito Público, em especial das doutrinas democráticas, não se pode afastar a ideia de que a soberania se conforma no conjunto de jurisdições asseguradas internacionalmente ao Estado para que o mesmo possa, segundo seus

\footnotetext{
${ }^{85}$ Vaugham Lowe, apudJANKOV, Direito Internacional penal..., p. 69.

${ }^{86}$ MELLO, Celso D. de Albuquerque. Curso de Direito Internacional público, t. I, 13 ed., Rio de Janeiro: Renovar, 2001, p. 428.

${ }^{87}$ Que exista um estreito liame entre soberania e poder constituinte originário não dá no mesmo que se afirmar a existência de identidade entre os dois institutos.

${ }^{88}$ BULOS, Uadi Lamêgo. Curso de direito constitucional, São Paulo: Saraiva, 2007, pp. 284-287.
} 
princípios jurídicos fundamentais e sua cultura, se autogovernar mediante um grau mínimo de autonomia em relação aos demais entes existentes, Estados ou a sociedade internacional.

Não se trata, de outro giro, de negar a existência da soberania, enquanto expressão englobante do conjunto de jurisdições nacionais, mormente na atual etapa do Direito Internacional em que o fenômeno da internacionalização parece abarcar quase todos os assuntos que antes eram de competência exclusiva do Estado, mas de, primeiramente, restituir o conceito a sua estrutura jurídica fundamental, e, segundamente, afirmá-la como elemento caracterizador do Estado Constitucional de Direito em suas relações com o Direito Internacional, pois, conforme Markus Kotzur ${ }^{90}$,

Quem abandona à soberania, desconhece não somente a realidade social, como também o conteúdo jurídico do conceito, assim como a simples necessidade que as comunidades políticas têm de contar com uma capacidade, competencialmente garantida, de atuação e configuração.

Quem, por outro lado, continua sustentando a habitual, mas questionável equação entre povo, Estado e nação, não é menos cego ante a realidade e frente à necessidade de dispor de uma noção de soberania que the seja correspondente.

Assim entendida, a soberania em sua dimensão interna, abarca, segundo o Direito Internacional, três tipos de jurisdições ${ }^{91}$, a saber:

1. jurisdição prescritiva ou legislativa (prescreptive juridiction): se conforma no conjunto de competências constitucionais através das quais os Estados poderão impor, sob a ameaça de sanção jurídica, normas jurídicas que têm por finalidade, para ficar no locus clássico, organizar o Estado e reger as relações jurídicas, públicas ou privadas.

2. jurisdição adjudicativa ou judicial (adjucative jurisdiction): expressão sinônima àquela utilizada em nível interno para identificar a uma das funções soberanas do Estado (jurisdicional), se consubstancia no conjunto de procedimentos públicos (processo) através dos quais os Estados julgam uma lide por violação a suas normas, sejam civis ou penais;

3. jurisdição executiva (executive ou enforcement jurisdiction): identifica a competência dos órgãos estatais de impor as sanções jurídicas a quem tenha sido responsabilizado pela violação às regras jurídicas, sejam elas de caráter cível ou penal.

No que concerne, doutro giro, à soberania em sua manifestação externa, a mesma deve ser interpretada a partir do princípio da igualdade entre os Estados, tal como proclamado pelo artigo 2, 1 da CONU e a DPDIRRACE/70, que expressamente empregam o termo igualdade soberana ${ }^{92}$.

\footnotetext{
${ }^{89}$ MIRANDA, Teoria do Estado..., pp. 376-378. No mesmo sentido BULOS, Curso de direito constitucional..., pp. $289-290$.

${ }^{90}$ KOTZUR, A soberania hoje..., p. 3.

${ }^{91}$ JANKOV, Direito Internacional penal..., pp. 74-76. AKEHURST, Akehurt's modern introduction ..., pp. 109-110. SHAW, International law, pp. 645-650.

${ }^{92}$ Referida Resolução regulamenta este princípio nos seguintes termos: "The principle of sovereign equality of States - All States
} 
Conforme afirma Malcolm Shaw ${ }^{93}$,

Outro princípio fundamental é o da igualdade jurídica dos Estados, que é a igualdade de direitos e deveres. [Os] Membros, independentemente de seu tamanho ou poder, têm as mesmas capacidades e funções jurídicas, e têm igualmente o direito a um voto na Assembleia Geral das Nações Unidas. A doutrina jurídica da igualdade de Estados é uma categoria guarda-chuva que inclui em seu âmbito os direitos reconhecidos e obrigações que incidem sobre todos os Estados.

É óbvio, entretanto, que este princípio tem um cariz estritamente jurídico, objetivando assegurar a todos os Estado que, no exercício de suas prerrogativas e direitos internacionais, bem como na exigência do adimplemento de suas respectivas obrigações, estejam submetidos aos mesmos princípios e regras de direito, independentemente de suas reais condições de poder. Estas desigualdades, que têm uma implicação efetiva não só no exercício dos direitos e obrigações internacionais, mas também na concreta afirmação das políticas exteriores dos Estados é interpretado no contexto das relações internacionais a partir dos conceitos de simetria e assimetria de poder ${ }^{94}$, conceitos estes que permitem às relações internacionais interpretar o papel concreto que cada Estado joga no cenário internacional, bastando lembrar, nesse sentido, a distinção que existe no bojo das Nações Unidas entre membros permanentes e membros transitórios do CSONU. ${ }^{95}$

\section{Conforme Malcolm Shaw ${ }^{96}$}

A noção de igualdade perante o direito é aceita pelos Estados no sentido da igualdade de personalidade jurídica e capacidade. No entanto, não seria correto afirmar isso em termos de igualdade dos Estados na criação do direito. Os principais Estados sempre terão uma influência proporcional ao seu status, mesmo porque as suas preocupações são muito mais amplas, seus interesses mais profundos e seu poder mais eficaz.

Ora, é nesse ponto que se torna útil perquirir sobre o problema político, e não jurídico, que envolve o tema do Direito Penal Internacional e o da soberania.

Alisson M. Danner e Beth Simmons, analisando este problema em relação ao TPI, já que muitos Estados ainda não ratificaram o seu estatuto ${ }^{97}$, procuram interpretar este fato à luz daquilo que eles denominam de custos

enjoy sovereign equality. They have equal rights and duties and are equal members of the international community, notwithstanding differences of an economic, social, political or other nature. In particular, sovereign equality includes the following elements: a. States are judicially equal; b. Each State enjoys the rights inherent in full sovereignty; c. Each State has the duty to respect the personality of other States; d. The territorial integrity and political independence of the State are inviolable; e. Each State has the right freely to choose and develop its political, social, economic and cultural systems; f. Each State has the duty to comply fully and in good faith with its international obligations and to live in peace with other States."

${ }^{93}$ SHAW, International law..., p. 214.

94 DE ALMEIDA, Paulo Roberto. A ONU e a questão da assimetria de poder. Disponível em http://www.pralmeida.org/05DocsPRA/1427ONUassimetria.pdf, acessado em 20.10.2007, às 19:23:00.

95 "A desigualdade no Conselho de Segurança é deliberada. Como ouvi de um representante norte-americano quando com ele conversava sobre o assunto: "é desigual como a vida é desigual.".' SOARES, João Clemente Baena. $O$ conselho de segurança da ONU. Disponível em http:/ / www.funag.gov.br/conselho-de-seguranca-baena-soares.pdf, acessado em 09.08.2006, às 1:00:00.

${ }^{96}$ SHAW, International law..., p. 215.

${ }^{97}$ Dos cinco membros permanentes do CSONU, somente o Reino Unido (em 04/10/2001) e França (em 05/09/2000) ratificaram o ETPI, os demais (EUA, China e Rússia), não. 
de soberania ${ }^{98}$ :

Nós usamos a expressão "custos de soberania" para nos referir aos custos que o Estado incorre, delegando uma função normalmente executada internamente, a uma instituição sobre a qual tem pouco, se algum, controle. Para um Estado, ceder autoridade para a aplicação da legislação penal que seria normalmente regulamentada internamente impõe um alto custo à soberania tanto mais no caso do TPI por causa de seu foco em processar líderes. O atual Promotor do TPI, por exemplo, emitiu uma nota pública declarando que ele irá se concentrar nos criminosos de alto nível. O anterior Promotor do ICTY [Ex-Iugoslávia] e o do ICTR [Ruanda] tem seguido uma estratégia semelhante. Este alto custo à soberania potencialmente extraído pelo TPI, no entanto, não tem detido todos os Estados de se unirem à instituição. Em verdade, é o nosso argumento, é precisamente a imposição de custos ex postpor violações que certos Estados acham o TPI tão atraente.

[...] Outros aspectos do Estatuto de Roma também aumentam a probabilidade de que alguns Estados-Membros terão de pagar os custos de soberania. $\mathrm{O}$ Estatuto de Roma não permite que os Estados façam reservas às suas disposições. Enquanto muitos tratados permitem aos Estados escolher se comprometer com algumas disposições, mas não outras, $\mathrm{o}$ Estatuto de Roma apresenta aos Estados uma escolha do tipo tudo-ou-nada. Além disso, o TPI não reconhece nenhuma das imunidades tradicionalmente reconhecidas aos chefes de Estado e outros altos funcionários pelo Direito Internacional. Na verdade, o tratado desconsidera (override) qualquer imunidade que os Estados possam conceder a seus servidores em seus sistemas internos. Assim, não há nenhuma imunidade presidencial, parlamentar ou legislativa no TPI, mesmo para os servidores que atualmente estejam exercendo estas funções. Por isso, qualquer Estado que se torne parte do TPI deve permitir a possibilidade muito real de que suas figuras de alto escalão possam ser processadas neste Tribunal.

Já M. Cherif Bassiouni em sua Henry J. Miller Distinguished Lecture99, proferida em 2006 na Faculdade de Direito da Universidade do Estado da Geórgia, interpreta este conflito político partindo de um possível paralelismo entre o "instinto de sobrevivência" que seria compartilhado tanto pelas espécies animais como pelas sociedades politicamente organizadas (leia-se Estados), e que no caso destas últimas, se manifestaria no contínuo processo histórico de afirmação do princípio do Estado de Direito (Rule of Law), mas que, mesmo passados milhares de anos, ainda se encontra em Estado de desenvolvimento no atual estágio da globalização, mormente se este paralelismo organizacional for estendido às relações interestatais. Isto porque, ao se analisar estas últimas em termos políticos, vê-se uma prevalência dos interesses nacionais em detrimento dos valores que seriam compartilhados (commonly-shared values) por todos os membros da sociedade internacional, nada obstante o ingresso destes últimos no processo de decisão internacional:

Reduzido a seus fundamentos, o que motiva os Estados em suas relações não são os valores duradouros que unem os seres humanos, mas os interesses cuja importância e oportunidade se encontram em fluxo constante. Assim, o traço dominante das relações interestatais caracteriza-se pelos interesses do Estado. No entanto, é evidente a partir da evolução das relações interestatais e internacionais desde a Segunda Guerra Mundial, até agora definido pelo conceito de Westfália de soberania e pelo conceito hegeliano de interesse do Estado, freado tanto pela prudência como pelo bom-senso, que tenha ocorrido uma mudança

\footnotetext{
${ }^{98}$ DANNER, SIMMONS, Sovereignty costs ..., pp. $5 / 7$.

${ }^{99}$ BASSIOUNI, The perennial conflict between..., passim.
} 
significativa. Isto é evidenciado por considerações dos valores comumente compartilhados que transcendem à busca unilateral e a preservação do poder e da riqueza que agora fazem parte da equação mundial.

E conforme exemplifica a história do Direito Penal Internacional, em especial após o desbloqueio das vias em 1989, a consolidação da justiça internacional para a persecução dos Core Crimes ainda estará, por muito tempo, dependente da cooperação dos Estados. E esta cooperação também estará - sempre? - condicionada à aferição pelos próprios Estados dos interesses historicamente situados no momento em que a mesma tiver que se concretizar, seja no cooperar com os Tribunais Internacionais, seja no exercer a jurisdição universal em relação aos crimes internacionais.

Agora, é interessante perceber como a própria estrutura das normas internacionais propicia esta análise de custos e oportunidades que entram em jogo na relação entre soberania e Direito Internacional no geral, e Direito Penal Internacional no particular, já que, conforme leciona Jose Antonio Pastor Ridruejo ${ }^{100}$,

Comparado com os direitos internos dos Estados, o Direito Internacional se nos apresenta como uma disciplina jurídica especialmente problemática, caracterizada por carências institucionais que motivam incerteza e relativismo no plano normativo, graves insuficiências na prevenção e sanção das violações e uma excessiva politização (politización extendida) ainda que não absoluta - na solução de controvérsias, quando não a impossibilidade de sua composição (arreglo). Vamos explicar estas densas ideias nas linhas que seguem.

Não existe ainda na sociedade internacional um órgão normativo equiparável àquele que nos Estados exerce o poder legislativo [...] Assim [...] são os próprios Estados que criam o Direito Internacional, que são, ao mesmo tempo, os principais destinatários do ordenamento [...] Outra chamativa característica da disciplina no plano normativo é a abundância da denominadas obrigações de comportamento. Efetivamente, junto às normas que estabelecem obrigações de resultado, que são aquelas que impõe aos Estados o dever de alcançar um determinado resultado (por exemplo, a abstenção do recurso ou a ameaça de uso da força), existem normas que não contém senão obrigações de comportamento, isto é, o dever de pôr os meios para conseguir um resultado, mas sem taxativamente exigir a sua consecução (por exemplo, o de procurar chegar à solução de controvérsias internacionais). Pois bem, como a execução desse último tipo de normas deixa grandes margens de discricionariedade aos destinatários, a verificação de seu descumprimento é extremamente problemática [...]

As incertezas normativas de que antes falamos exigiriam um sistema eficaz de solução de controvérsias na sociedade internacional. Mas também nesse aspecto a situação não é satisfatória, pois não há em referida sociedade um mecanismo equiparável ao que existe nos Direitos internos que, como é bem sabido, instituíram há muito tempo o processo judicial obrigatório substituível em determinadas matérias pela arbitragem [...] Ante tais controvérsias os Estados adotam uma atitude política, e não jurídica - fala-se por isso de controvérsias políticas - e de tentar solucionar a disputa por meios políticos, nos quais conservam sua liberdade soberana de ação e decisão, e não por meios jurisdicionais. Meios políticos que podem ser profundamente injustos se o nível de poder dos Estado é desigual e que podem ser ineficazes se tal poder for comparável.

${ }^{100}$ PASTOR RIDRUEJO, Curso de derecho internacional público..., pp. 37-40. 


\section{A GUISA DE CONCLUSÃO}

Assim, de um lado, é fato que a internacionalização do Direito Penal na sua variante de persecução aos crimes internacionais próprios, mitiga - não anula nem suprimi - a soberania dos Estados, na medida em que os Tribunais Internacionais, orientados pelas regras da primazia ou da complementariedade, executam, legitimamente ${ }^{101}$, atributos que seriam exercidos pelos Estados; mas, de outro lado, esta mitigação não pode, nem deve ser encarada como uma forma de supressão do papel importantíssimo que os Estados ainda jogam na sociedade internacional ${ }^{102}$, nem deve servir de espeque para que os Estados se abstenham de cooperar internacionalmente na efetivação de um sistema internacional mais eficaz na tutela dos direitos humanos.

A afirmação acima feita se funda num postulado teórico de caráter ideológico, que busca conciliar, de forma responsável, duas teorias das relações internacionais que se opõem numa lógica do "tudo-ou-nada", a saber, realismo e idealismo; aquele orientado exclusivamente pela realpolitik, persegue uma lógica que exclui qualquer outra consideração que não seja o interesse do Estado; este orientado por pretensões de institucionalização da sociedade internacional que teriam, como meta final, a eliminação do próprio Estado e a constituição de uma comunidade internacional. ${ }^{103}$

Ora, propugnar pelo constante e irrefreável aperfeiçoamento das instituições internacionais no geral, e do sistema penal internacional em particular, uma luta manifestamente idealista para se enfrentar aquilo que Kai Ambos denomina de lacuna da punibilidade fática ${ }^{104}$, não implica, necessariamente, na infirmação da independência do Estado nacional na condução de sua política internacional, ainda mais porque nada obsta que argumentos idealistas revistam-se de meras justificativas políticas a ensejar uma ilegítima intervenção internacional ${ }^{105}$. Parafraseando Pastor Ridruejo ${ }^{106}$, para ser-se idealista é preciso, antes de tudo, ser-se realista, isto

\footnotetext{
${ }^{101}$ Sobre a legitimidade da criação dos TPIExIug e TPIR pelo CSONU nos termos do Capítulo VII da CONU, SCHABAS, The UN international criminal tribunals ..., pp. 3-34.

${ }^{102}$ Sobre este tema, Prosper Weil parece ter jogado uma pá de cal nas teorias que sustentam quer a supressão do Estado como sujeito do Direito Internacional quer o surgimento, pós 89, de uma comunidade internacional. Conforme o autor, os Estados ainda são os principais sujeitos do Direito Internacional, sendo o Direito Internacional ainda hoje fundamentalmente interestatal. WEIL, Le droit international em quête..., pp. 26-39 e 88-128.

${ }^{103}$ PECEQUILO, Cristina Soreanu. Introdução às relações internacionais, Petrópolis: Vozes, 2004, pp. 116-140.

${ }^{104}$ AMBOS, A parte geral do Direito Penal Internacional..., p. 40; AMBOS, Kai. Impunidade por violação dos direitos humanos e o Direito Penal Internacional, trd. Alexandra Rosado, Revista Brasileira de Ciências Criminais, ano 12, n. 49, São Paulo: RT, 2004, pp. 48-88. A lacuna é fática, e não jurídica, porque a maioria dos ordenamentos jurídicos contemporâneos pune, com graus bastante variados de penas, a maioria dos crimes que constituem os crimes internacionais próprios, muito embora não os tenha tipificado especificamente nessa rubrica. O problema é fático-político, na medida em que estes crimes, sendo praticados segundo uma decisão política de Estado, não são ou não serão punidos por razões políticas, e não jurídicas, como ocorre, na maioria dos caos, com a promulgação das leis de anistia.

${ }^{105}$ Caso paradigmático foi, sem dúvida, o da intervenção militar no Iraque sob o argumento de que este Estado, descumprindo resoluções do CSONU, detinha armamentos de destruição em massa.

${ }^{106}$ PASTOR RIDRUEJO, Curso de derecho internacional..., pp. $42-43$.
} 
é, sustentar a necessidade de aperfeiçoamento dessas instituições com pés firmes na realidade das relações internacionais tal como elas efetivamente se concretizam e de conformidade com o Direito Internacional posto, e não em ideais (ainda) inatingíveis e moralizações que tendem a excluir a própria esfera política de que se revestem as relações entre Estados.

É nesse sentido, portanto, que seguem os magistérios de M. Cherif Bassiouni e Antonio Cassesse.

Bassiouni ${ }^{107}$, em sua já citada Miller Lecture aponta a necessidade estratégica de se conciliar o aperfeiçoamento do sistema internacional de proteção aos direitos humanos (constituição contínua do Rule of Law em nível internacional), no qual o Direito Penal Internacional ocupa uma posição essencial, com os interesses dos Estados, e ele o faz nos seguintes termos:

[A] Experiência jurídica demonstra que a enunciação de direitos sem [os] concomitantes remédios são declarações de Pirro, e que os remédios sem aplicação são promessas vazias. No entanto, por mais moralmente atraentes que esses argumentos sobre os direitos humanos individuais e a sua aplicabilidade possam ser, ainda é necessário oferecer aos Estados um incentivo para "comprar" o reconhecimento de tais direitos e sua aplicação. A necessidade de tal incentivo surge porque os resultados decorrentes de um sistema jurídico internacional, baseado no Estado de Direito, são suscetíveis de ser prejudicial para os interesses do Estado, e pode constituir numa limitação à sua soberania, tal como decorrente do anterior sistema de Westfália que esta a minguar. [Para que] Os Estados "comprem" o argumento, [este] deve necessariamente incluir os correspondentes interesses do Estado. $\mathrm{O}$ argumento fundamental desta proposição é que a proteção dos direitos humanos individuais, bem como dos direitos humanos coletivos, aumentam a paz e a segurança, reduz os conflitos nacionais, regionais e mundiais, e é, em última análise, mais econômico do que ter que se envolver em operações militares de intervenção humanitária, certamente por haver Estados envolvidos em conflitos regionais. Em outras palavras, um argumento utilitarista sobre os direitos humanos que avança em sua reflexão sobre os interesses do Estado [in other words, the argument advances the utilitarian side of human rights in its reflection on state interests].

Já Antonio Cassesse ${ }^{108}$, após responder afirmativamente ao problema da mitigação da soberania estatal por conta do desenvolvimento da jurisdição penal internacional - ele cita como exemplo a não validade das leis de anistia, a constituição dos Tribunais $A d$ Hoc por decisão do CSONU, a aceitação de que os Core Crimes violam normas internacionais de caráter jus cogens e instituidoras de obrigações erga omnes etc -, afirma que esta limitação é mais aparente do que real, na medida em

[...] esses tribunais não têm o poder de "mandar", pois não dispõem de polícia judiciária [...] eles devem se dirigir às autoridades nacionais. Esses tribunais são, portanto, desprovidos do poder de coerção; esse poder permanece nas mãos dos Estados soberanos. Mesmo quando se trata de implantar aquelas inovações importantes [...] as jurisdições penais internacionais esbarram no muro da soberania [...] podem argumentar mil vezes junto a um Estado que a entrega de um de seus nacionais acusado de crimes gravíssimos não é contrário à Constituição nacional [...] e que, de todo modo, decorre das obrigações internacionais desse Estado. O que sempre acontece é que se o Estado se opõe, o indivíduo permanece sob sua

\footnotetext{
${ }^{107}$ BASSIOUNI, The perennial conflict between...

${ }^{108}$ CASSESSE, Existe um conflito insuperável..., pp. 7-9.
} 
autoridade, e a jurisdição internacional não tem nenhuma arma eficaz à sua disposição para constranger o Estado [...] O mesmo ocorre [...] da anulação das leis internas por jurisdição internacional. Se o Estado em questão recusa-se a curvar-se á decisão internacional e decide continuar a considerar suas leis válidas e eficazes, a jurisdição internacional pode "condenálo", isto é, reiterar que esse Estado violou o Direito Internacional, mas não dispõe de nenhum meio de coerção legal [...] O Estado soberano ainda continua vigoroso; ele ainda é uma espécie de Deus imortal; ele ainda tem em suas mãos a espada e não tem nenhuma intenção de entregá-la às instituições internacionais.

E a forma encontrada por Antonio Cassesse ${ }^{109}$ para enfrentar a necessária conciliação entre Direito Penal Internacional e soberania estatal se encontra não na infirmação definitiva desta última, mas no aperfeiçoamento do princípio da jurisdição universal ${ }^{110}$, através do qual os Estados exerceriam concorrencialmente a persecução penal dos crimes internacionais com os Estados que, pelo princípio da territorialidade, seriam competentes.

Assim, parece ser correta a afirmação inicialmente feita de que a polêmica entre soberanistas e internacionalistas com relação ao Direito Penal Internacional não é nada mais do que um litígio de caráter eminentemente discursivo no qual os dois lados da controvérsia se digladiam tendo por meta justificar uma forma de exercício de poder, quando, na verdade, a prática do Direito Internacional contemporâneo se orienta no sentido de compatibilizar os dois polos da controvérsia, sem a qual, no atual estágio da sociedade internacional, o trabalho da justiça internacional restará ineficaz.

Não parece ser menos óbvio, entretanto, que os Estados constitucionais, vinculados que estão interna ${ }^{111}$ e externamente aos projetos internacionais de proteção aos Direitos Humanos, devem cooperar internacionalmente para a consolidação da justiça internacional, pois nesse tipo de Estado a soberania somente terá um significado efetivamente jurídico-político no atual estágio da história humana quando, em última instância, for a dignidade humana, e não interesses outros, que orientar o seu comportamento para dentro e para fora.

Para dentro na medida em que reconhece a necessidade de a sua jurisdição penal também estar a serviço da persecução dos autores de crimes internacionais; externamente na medida em que coopera, com outros Estados ou com os tribunais internacionais, no enfrentamento da impunidade dos crimes contra a humanidade.

Markus Kotzur ${ }^{112}$, nesse sentido, parece oferecer palavras chave para se compreender o tema:

$\mathrm{O}$ aspecto cooperativo tem consequências imperativas. "No conceito jurídico-estatal de

\footnotetext{
${ }^{109}$ CASSESSE, Existe um conflito insuperável..., pp. 9-24.

${ }^{110}$ Kai Ambos vislumbra nessa tese, sem que faça citação expressa a Antonio Cassesse, um prejuízo à consolidação do Tribunal Penal Internacional como instância supranacional de persecução aos crimes internacionais, já que no âmbito da jurisdição universal os Estados detêm uma margem de decisão política que poderia ilidir a efetivação da cooperação internacional horizontal. AMBOS, Kai. Processando crimes internacionais em nível nacional e internacional: justiça x Realpolitik, in JAPIASSÚ, Carlos E. Adriano (Org). Direito Penal Internacional estrangeiro e comparado: Rio de Janeiro: Lumen Juris, 2007, pp. 86-88.

${ }^{111}$ VÁZQUEZ, Rodolfo. Entre la liberdad y la igualdad: introducción a la filosofía del derecho, Madri: Trotta, 2006, pp. 181-207.

${ }^{112}$ KOTZUR, A soberania hoje...
} 
soberania tem que estar contido o fato da coordenação e conjunção dos Estados como momento material, de tal modo, que seus limites estejam definidos pelo valor próprio do ser humano". Dito de outro modo: o conceito material de soberania se apoia numa dupla premissa. Tal qual o Estado Constitucional, funda-se na dignidade humana e no valor próprio da pessoa como "premissa antropológica", contendo, no entanto, ao mesmo tempo, a dimensão da cooperação, já que o Estado contemporâneo não se caracteriza tanto pela sua magnitude abstrata, e sim pela pluralidade de suas vinculações jurídicas e fáticas. Se a soberania foi, historicamente falando, resultado da concentração de poder nas mãos do soberano, e se foi dessa forma que adquiriu seus conteúdos para depois, gradualmente, ser acolhida pelo Estado Constitucional, então, hoje em dia, é necessário que o poder soberano se des-concentre novamente. Os critérios são o "exercício cooperativo da soberania" e o princípio da subsidiariedade como "condição da realização da soberania". As unidades de decisão subsidiárias e parcialmente soberanas fundam-se numa unidade de ação da qual derivam, e não somente para a Europa, conteúdo, forma e Constituição.

Um conceito de soberania que seja igualmente válido tanto para a doutrina do direito constitucional como para o Direito Internacional já pressupõe este elemento cooperativo. $\mathrm{O}$ poder público, que atualmente tanto é exercido por unidades estatais como por unidades supraestatais surgidas dos processos de integração, não pode ser explicado por meio das categorias unidimensionais de uma teoria do Estado positivista, mas que deve ser extraído a partir da realidade do mundo globalizado dos Estados. Os textos das constituições nacionais fazem neste sentido uma contribuição indispensável. Em seu preâmbulo e em seus artigos 23, 24 e 25, aponta a Lei Fundamental de Bonn, como agudamente o tem assinalado Konrad Hesse, "para além de si mesma". Novos propósitos terminológicos substituem a "supremacia absoluta” como característica da soberania. A interação de competências relativas, a "soberania compartilhada", o "poder da organização internacional", ou o "poder da integração supranacional”, constituem outras tantas palavras-chave. Em última instância, a imagem corrente da "superposição" do Direito Internacional ou o europeu à soberania não é exato. Não é que uma esfera soberana se superponha à outra, mas sim que os diversos âmbitos de competências e os espaços soberanos se coordenam entre si e se vinculam através de um mecanismo de entrosamento de um com o outro. $\mathrm{O}$ cânon normativo típico, que manifesta a decisão do Estado Constitucional a favor da cooperação internacional, estrutura a soberania muito mais do que a desarticula. A relativização da soberania não leva a lhe dizer adeus, mas à sua reinterpretação como garantia estrutural.

Se o contínuo aperfeiçoamento da justiça internacional ainda é dependente da cooperação internacional dos Estados, sem a qual ela não logra ser eficaz, o Estado Constitucional, devendo-se se afastar dos paradigmas dos Estados fechados ou dos Estados selvagens ${ }^{113}$, assume como uma sua tarefa, o "[...] desenvolvimento de um "Direito Internacional cooperativo": a caminho de um "Direito Comum de Cooperação" [...]" sendo, pois, "[...] a resposta interna do Estado Constitucional livre e democrático à mudança no Direito Internacional e ao seu desafio que levou a formas de cooperação”. ${ }^{114}$

Em outras palavras, Estado Democrático de Direito, o mesmo que Estado Constitucional, deve se caracterizar, sempre, pela cooperação internacional em geral, e na cooperação penal em particular, pois é nesse cooperar que a meta de asseguração dos Direitos Humanos interna e internacionalmente assegurados serão objeto de proteção efetiva.

\footnotetext{
${ }^{113}$ HÄBERLE, Peter. Estado constitucional cooperativo, Rio de Janeiro: Renovar, 2007, p. 7.
} 


\title{
INTERNATIONAL CRIMINAL LAW, CONSTITUTIONAL STATE AND THE PROBLEM OF THE SOVEREIGNTY MITIGATION ON THE PERSECUTION OF CORE CRIMES
}

\begin{abstract}
In this paper we discuss the issues related to international criminal law, the consolidation of international justice in the prosecution of core crimes - through the International Criminal Tribunals (direct enforcement) or universal jurisdiction (indirect enforcement) - and the problem of the relationship between sovereignty and international jurisdiction, intending to resolve the controversy between consolidation and a possible mitigation of state sovereignty. This solution is found in two distinct poles: on the one hand, the continuous progress of international justice tends to mitigate the criminal jurisdiction of states over the previous exclusivity for the prosecution of international crimes, on the other hand, this progress is still conditional cooperation states, without which international justice is ineffectively, hence the duty of states to cooperate internationally to address the problem of impunity for crimes against humanity.
\end{abstract}

Keywords: Criminal International Justice, Core Crimes, Sovereignty, International Cooperation

\section{REFERENCIAS}

ACCIOLY, Hildebrando. Tratado de Direito Internacional público, vol. II, 3 ed., São Paulo: Quartier Latin, 2009.

AGAMBEN, Giorgio. Il regno e la gloria: per una genealogia teologica dell'economia e del governo. Homo sacer, II.2, Vicenza: Neri Pozza, 2007.

AKERURST, Michael, MALANCZUK, Peter (org.). Akehurt's modern introduction to internacional law, 17 ed., New York: Routledge, 1997.

AMBOS, Kai. Impunidade por violação dos direitos humanos e o Direito Penal Internacional, trd. Alexandra Rosado, Revista Brasileira de Ciências Criminais, ano 12, n. 49, São Paulo: RT, 2004, pp. 48-88.

Processando crimes internacionais em nível nacional e internacional: justiça x Realpolitik, in JAPIASSÚ, Carlos E. Adriano (Org). Direito Penal Internacional estrangeiro e comparado: Rio de Janeiro: Lumen Juris, 2007, pp. 75-89.

A parte geral do Direito Penal Internacional: bases para uma elaboração dogmática, trd. Carlos E. A. Japiassú e Daniel A. Raizman, São Paulo: RT, 2008.

BADINTER, Robert. Soberania dos Estados: reflexões gerais, in CASSESSE, Antonio, DELMAS-MARTY, Mireille (Org.). Crimes internacionais e jurisdições internacionais, trd. Silvio Antunha, Barueri: Manole, 2004.

BASSIOUNI, M. Cherif. Introduction to international criminal law, [s.ed], New York: Transnational

\footnotetext{
${ }^{114}$ HÄBERLE, Estado constitucional cooperativo..., p. 10.
} 
Publishers, 1997.

"Universal jurisdiction for international crimes: historical perspectives and contemporary practice". Virginia Journal of International Law 42, n. 81, fall 2001.

The perennial conflict between international criminal justice and realpolitik, $38^{\text {th }}$ Henry J. Miller

Distinguished Lecture, Georgia State University College of Law, disponível em http://law.gsu.edu/Miller_Lecture/2006/MillerLecture-S06-BassiouniDraft.pdf, acessado em 15/05/2012, às 15:45:00.

Crimes against humanity: historical evolution and contemporary application, Cambridge: Cambridge University Press, 2011.

BAZELAIRE, Jean-Paul, CRETIN, Thierry. A justiça penal internacional: sua evolução, seu futuro de Nuremberg a Haia, trd. Luciana P. Venâncio, Bauru: Manole, 2004.

BOBBIO, Norberto. O problema da guerra e as vias da paz, trd. Álvaro Lorencini, São Paulo: Editora UNESP, 2003.

A era dos direitos, 9 ed., trad. Carlos N. Coutinho, Rio de Janeiro: Campus, 2004.

POLITO, Pietro (Org.). O terceiro ausente: ensaios e discursos sobre a paz e a guerra, trd. Daniela Versiani, Barueri: Manole, 2009.

BODINO, Juan. Los seis libros de la Republica, t. I, trd. Gaspar de A. Isunza, Madri: Centro de Estudios Constitucionales, 1992.

BROOK, Timothy. O chapéu de Vermeer: o século XII e o começo do mundo globalizado, trd. Maria B. de Medina, Rio de Janeiro: Record, 2012.

BROWNLIE, Ian. Principles of public international law, 5 ed., New York: Oxford University Press, 1998.

BULOS, Uadi Lamêgo. Curso de direito constitucional, São Paulo: Saraiva, 2007.

CAPPS, Patrick, EVANS, Malcolm, KONSTADINIDIS, Stratos. Asserting jurisdiction: International and European legal approachs, Oxford: Hart Publishing, 2003.

CASSESSE, Antonio. Existe um conflito insuperável entre soberania dos Estados e justiça penal internacional?, in CASSESSE, Antonio, DELMAS-MARTY, Mireille (Orgs.). Crimes internacionais e jurisdições internacionais, trd. Silvio Antunha, Barueri: Manole, 2004.

CASTELSS, Manuel. A era da informação: economia, sociedade e cultura, vol. I: A sociedade em rede, trd. Klauss B. Gerhardt, 4 ed., São Paulo: Paz e Terra, 2005.

A era da informação: economia, sociedade e cultura, vol. II: O poder da identidade, trd. Klauss B. Gehardt, 5 ed., São Paulo: Paz e Terra, 2006.

CRUVELLIER, Thierrry. Court of remorse: inside the International Criminal Court for Rwanda, trd. Chari Voss, Madison: University of Wisconsin Press, 2006.

CRYER, Robert. International Criminal Law vs State Sovereignty: Another Round? The European Journal of International Law vol. 16, n. 5, 2006.

DANNER, Allison Marsten, SIMMONS, Beth. Sovereignty costs, credible commitments, ans the 
International Criminal Court. Disponível em www.law.yale.edu/documents/pdf/Faculty/DannerSimmons07.pdf, acessado em 10/06/2013, às 17:00:00.

DE ALMEIDA, Paulo Roberto. A ONU e a questão da assimetria de poder. Disponível em http://www.pralmeida.org/05DocsPRA/1427ONUassimetria.pdf, acessado em 20.10.2007, às 19:23:00.

DE OLIVEIRA, Marcus Vinícius Xavier. "Da inconstitucionalidade dos artigos 70, $\$ 11^{\circ}$ e $8 \circ$ do Código Penal por violação ao princípio ne bis in idem", Revista Quaestio Iuris, Rio de Janeiro, 2012, pp. 1-31.

Guerra ao terror: da biopolítica à bioguerra, Porto Velho: Edufro, 2013.

A internacionalização do direito da execução penal: em que(quais) sentido(s)?, in DE OLIVEIRA, Marcus Vinícius Xavier. Temas escolhidos sobre a internacionalização do Direito Penal, Porto Alegre: Fi, 2014, pp. 274-306.

DE OLIVEIRA, Odete Maria. Teorias globais, Vol. I: Elementos e estruturas, Ijuí: Editora Unijuí, 2005, pp. 3143.

DE VATTEL, Emer. O direito das gentes, trd. Vicente Marotta Rangel, Brasília: IPRI/Editora da UNB, 2004.

DELMAS-MARTY, Mireille. Por um direito comum, trd. Maria E. de A. P. Galvão, São Paulo: Martins Fontes, 1994.

Trois défis pour un droit mondial, Paris: Éditions du Seuil, 1998.

DOLINGER, Jacob. Direito Internacional privado: parte geral, 6 ed., Rio de Janeiro: Renovar, 2001.

ESPOSITO, Roberto. Immunitas. Protezione e negazione dela vitta, Turín: Einaudi, 2002.

Bíos: biopolítica e filosofia, Turín: Einadi, 2004.

"Filosofia e biopolítica”, trd. Marcus Vinícius Xavier de Oliveira, Ethic@, vol 9, n. 2, Florianópolis, 2010, pp. 369-382.

Comunidade e violência, in DANNER, Fernando, DANNER, Leno Francisco (Org). Temas de filosofia política contemporânea, trd. Marcus Vinícius Xavier de Oliveira, Porto Alegre: Editora Fi, 2013, pp. 1332.

FOUCAULT, Michel. Em defesa da sociedade, trad. Maria Ermantina Galvão, São Paulo: Martins Fontes, 2002.

O que é a crítica? Crítica e Aufklärung, trad. Gabriela Lafetá Borges, disponível em http://www.unb.br/fe/tef/filoesco/foucault/, acessado em 15 de fevereiro de 2006, às 3:00:00.

Soberania e disciplina, in Microfísica do poder, 23 ed., trad. Maria Teresa de Oliveira e Roberto Machado, São Paulo: Graal, 2007.

GOUVEIA, Jorge Bacelar. Manual de Direito Internacional público, Rio de Janeiro: Renovar, 2005.

GROTIUS, Hugo. O direito da guerra e da paz, vol. I, trd. Ciro Mioranza, Ijuí: Editora Unijui, 2044.

GUGGENHEIM, Paul. Contribution a l'historie des sources du Droit des Gens, RCADI, vol. 94, 1958.

HÄBERLE, Peter. Estado constitucional cooperativo, Rio de Janeiro: Renovar, 2007.

HAGAN, John. Justice in the Balcans: prosecuting war crimes in the Hague Tribunal, Chicago: Chicago University Press, 2003. 
HUNTINGTON, Samuel P. "The Clash of Civilizations?”, Foreign Afairs vol. LXXII, n. 3, 1993, pp. $22-49$. IANNI, Octávio. Teorias da globalização, 12 ed., Rio de Janeiro: Civilização Brasileira, 2004, pp. 14-15.

INTERNATIONAL COURT OF JUSTICE. Reservation to the Convention on the prevention and punishment of the crime of genocide. Advisory opinion of 28 May 1951, disponivel em http://www.icjcij.org/docket/index.php?p1=3\&p2=4\&k=90\&case=12\&code=ppcg\&p3=4, acessado em 20/01/2006, às 14:00.

INTERNATIONAL COURT OF JUSTICE. CIJ. Arrest Warrant of 11 April 2000 (Democratic Republic of the Congo v. Belgium), disponível em http://www.icj-cij.org/docket/files/121/7081.pdf,acessado em 25/07/2012, às 10:00.

JANKOV, Fernanda F. F. Direito Internacional penal: mecanismos de implementação do Tribunal Penal Internacional, São Paulo: Saraiva, 2009.

JAPIASSÚ, Carlos Eduardo Adriano. O Tribunal Penal Internacional: a internacionalização do Direito Penal, Rio de Janeiro: Lumen Juris, 2004.

(Org). Direito Penal Internacional estrangeiro e comparado: Rio de Janeiro: Lumen Juris, 2007.

KELSEN, Hans. Les rapports de sytème entre le Droit Interne et le Droit International, RCADI, vol 14, 1926.

KOSKENNIEMI, Martti. Fragmentation of international law: difficulties arising from the diversification and the expansion of International Law - Report of the Study Group of the International Law Commission. INTERNATIONAL LAW COMMISSION, Fifty-eighth session, Geneva, 1 May-9 June and 3 July-11 August 2006.

KOTZUR, Markus. A Soberania Hoje. Palavras-Chave para um Diálogo Europeu Latino-Americano Sobre um Atributo do Estado Constitucional Moderno, trd. Marcus V. X. de Oliveira e Gabriel G. de Godói, Revista Quaestio Iuris, Rio de Janeiro, 2012, pp. 1-19.

LAMAZIÈRE, Georges. Ordem, hegemônia e transgressão, 2 ed., Brasília: Fundação Alexandre de Gusmão, 2010.

MAGALHÃES, José Luiz Quadros de. Direito constitucional, T. I, Belo Horizonte: Mandamentos, 2000.

MELLO, Celso D. de Albuquerque. Curso de Direito Internacional público, t. I, 13 ed., Rio de Janeiro: Renovar, 2001.

MIRANDA, Jorge. Teoria do Estado e da constituição, Rio de Janeiro: Forense, 2002.

PASTOR RIDRUEJO, Jose Antonio. Curso de derecho internacional público y organizaciones internacionales, 4 ed., Madri: Tecnos, 1992.

PECEQUILO, Cristina Soreanu. Introdução às relações internacionais, Petrópolis: Vozes, 2004. 
Pew-Templeton. Global Religious Future Project, disponível em http://www.globalreligiousfutures.org/explorer\#/?subtopic=15\&chartType=bar\&year=2010\&data_type=num ber\&religious_affiliation=all\&destination=to \&countries=Worldwide, acessado em 10/07/2013, às 17:50:00. ROSENNE, Shabtai. The perplexities of modern international law, Leiden: Martinus Nijhoff Publishers, 2004.

SANTOS, Boaventura de Sousa. Os processos da globalização. Disponível em http://www.eurozine.com/articles/2002-08-22-santos-pthtml, acessado em 20/02/201 1, às 23:35:00.

Para um novo senso comum: a ciência, o direito e a política na transição paradigmática. Vol. 1: A crítica da razão indolente: contra o desperdício da experiência, São Paulo: Cortez, 2001.

SCHABAS, William A. The UN international criminal tribunals: the former Yugoslavia, Rwanda and Sierre Leone, Cambridge: Cambridge University Press, 2006. 2011.

An introduction to the International Criminal Court, 4 ed., Cambridge: Cambridge University Press,

SCHMITT, Carl. Teologia política, trad. Elisete Antoniuk, Belo Horizonte: Del Rey, 2006.

SOARES, João Clemente Baena. O conselho de segurança da ONU. Disponível em http://www.funag.gov.br/conselho-de-seguranca-baena-soares.pdf, acessado em 09.08.2006, às 1:00:00.

TOMUSCHAT, Christian. Obligations arising for States without or against their will, RCADI 241, 1993.

TRIEPEL, H. Les rapports entre le Droit Interne et le Droit International, RCADI vol 1, pp. 73-122, 1923.

UNITED NATIONS OFFICE ON DRUGS AND CRIMES. The globalization of crime: a transnational organized crime threat assessment, UNODC: Viena, 2010, pp. 16-17. Disponível em http://www.unodc.org/documents/data-and analysis/tocta/TOCTA_Report_2010_low_res.pdf, acessado em 15/02/2011, às 14:00:00.

VARELLA, Marcelo D., DE OLIVEIRA, Vitor Eduardo Tavares. Da unidade à fragmentação do Direito Internacional: o caso mox plant. Revista da Faculdade de Direito da UFMG, Belo Horizonte, n. 54, jan-jun/2009.

VÁZQUEZ, Rodolfo. Entre la liberdad y la igualdad: introducción a la filosofia del derecho, Madri: Trotta, 2006.

WEIL, Prosper. Le droit international em quête de son identité, Cours géneral de droit international public, RCAD vol. 237, 19992.

Trabalho enviado em 30 de junho de 2017.

Aceito em 09 de novembro de 2017. 